HNF-39744

Revision 0

Volume 1

\title{
Sludge Treatment Project Alternatives Analysis Summary Report
}

Prepared for the U.S. Department of Energy Assistant Secretary for Environmental Management

Project Hanford Management Contractor for the

U.S. Department of Energy under Contract DE-AC06-08RL14788

CHIMHILL

Plateau Remediation Company

P.O. Box 1600

Richland, Washington 99352

Approved for Public Release;

Further Dissemination Unilimited 
HNF-39744

Revision 0

Volume 1

EDC \#: HNF-EDC-09-40074

\section{Sludge Treatment Project Alternatives Analysis Summary Report}

Project No: A-21C

Document Type: RPT

Program/Project: STP

J. R. Frederickson

AREVA

R. J. Rourk

J. O. Honeyman

Fluor Government Group

M. E. Johnson

R. E. Raymond

CH2M HILL Plateau Remediation Company

Date Published

January 2009

Prepared for the U.S. Department of Energy

Assistant Secretary for Environmental Management

Project Hanford Management Contractor for the

U.S. Department of Energy under Contract DE-AC06-08RL14788

\section{CH2MHILL}

Plateau Remediation Company

P.O. Box 1600

Richland, Washington
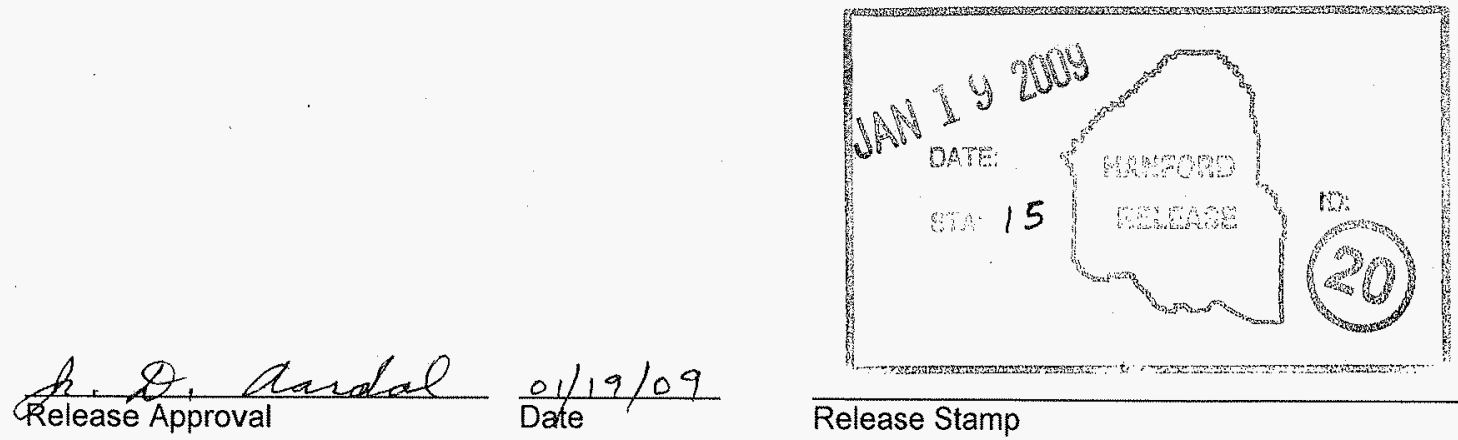

Release Stamp 
HNF-39744

Revision 0

TRADEMARK DISCLAIMER

Reference herein to any specific commercial product, process,

or service by trade name, trademark, manufacturer, or

otherwise, does not necessarily constitute or imply its

endorsement, recommendation, or favoring by the United

States Government or any agency thereof or its contractors or subcontractors.

This report has been reproduced from the best available copy.

Printed in the United States of America

Total Pages: 63 


\section{Table of Contents}

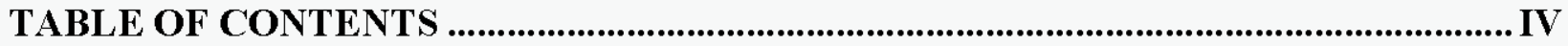

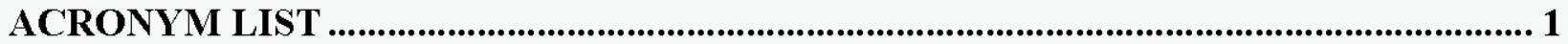

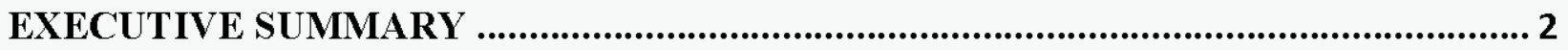

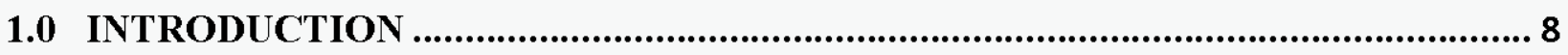

2.0 SLUDGE BACKGROUND AND HISTORY ........................................................ 10

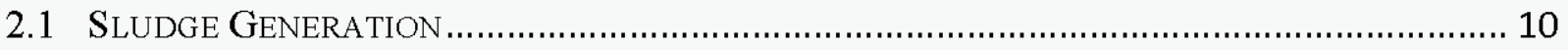

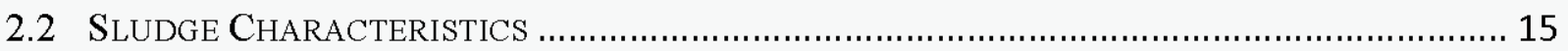

3.0 ALTERNATIVES ANALYSIS PROCESS .............................................................. 17

3.1 Description of the Alternatives Evaluation Process......................................... 17

3.2 Reducing the Number of Alternatives to THREe .............................................. 22

3.3 Process For REdUCING the Number of Alternatives to OnE .................................. 25

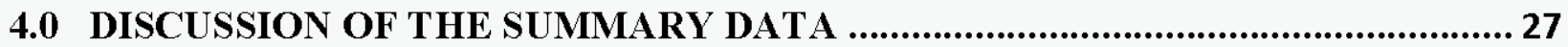

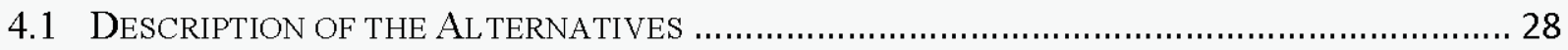

4.2 Evaluation of Alternatives using the Five Selection Criteria .......................... 33

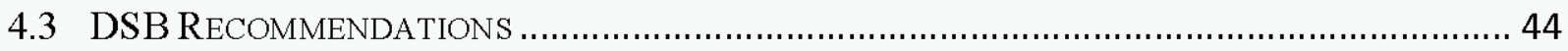

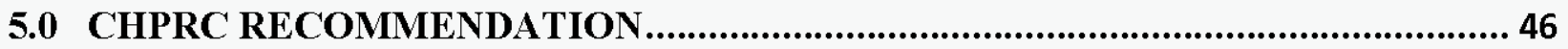

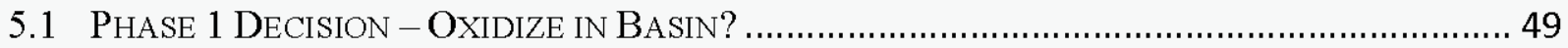

5.2 Phase 1 Decision - Store IN New Facility OR T Plant? .......................................... 50

5.3 CHPRC Actions to Mitigate DSB IdENTIFIED Risks ............................................... 52

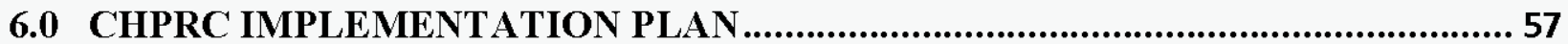

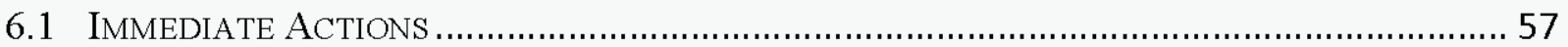

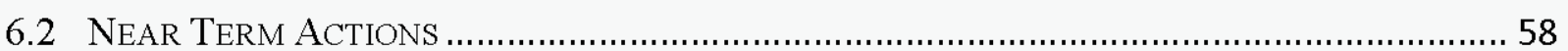

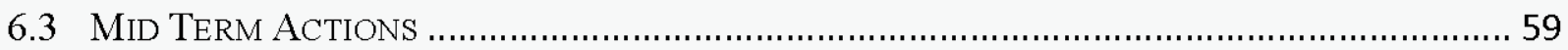




\section{Acronym List}

AACE

ALARA

CD

CERCLA

CHPRC

CH-TRU

CTE

DNFSB

DOE EM

DOE

DOE-RL

DSB

EPC

FDC

FGE

IRC

ISC

KOP

MT

NEPA

OIER

PBS

PMB

PUREX

REDOX

RH-TRAMPAC

RH-TRU

ROM

SDC

SME

STP

STSC

STS

TMP

TRA

TRL

TRU

TSCA

WIPP
Association for the Advancement of Cost Engineering

As Low As Reasonably Achievable

Critical Decision

Comprehensive Environmental Response, Compensation, and Liability Act

CH2M HILL Plateau Remediation Company

contact-handled transuranic

Critical Technology Element

Defense Nuclear Facility Safety Board

U. S. Department of Energy Environmental Management

U. S. Department of Energy

U. S. Department of Energy Richland Operations Office

Decision Support Board

engineering, procurement, and construction

functional design criteria

fissile grams equivalent

Independent Review Committee

interim storage container

knock-out pots

metric ton

National Environmental Policy Act

organic ion exchange resin

Project Breakdown Structure

Performance Management Baseline

Plutonium Uranium Extraction

Reduction-Oxidation

Remote-Handled Transuranic Waste Authorized Methods for Payload Control remote-handled transuranic

rough order of magnitude

seismic design category

subject matter experts

Sludge Treatment Project

Sludge Transport and Storage Container

Sludge Transport System

Technology Maturation Plan

Technology Readiness Assessment

Technology Readiness Level

transuranics

Toxic Substances Control Act

Waste Isolation Pilot Plant 


\section{Executive Summary}

Background: Highly radioactive sludge (containing up to 300,000 curies of actinides and fission products) resulting from the storage of degraded spent nuclear fuel is currently stored in temporary containers located in the $105-\mathrm{K}$ West storage basin near the Columbia River. The background, history, and known characteristics of this sludge are discussed in Section 2 of this report.

There are many compelling reasons to remove this sludge from the K-Basin. These reasons are discussed in detail in Section 1, and they include the following:

- Reduce the risk to the public (from a potential release of highly radioactive material as fine respirable particles by airborne or waterborne pathways)

- Reduce the risk overall to the Hanford worker

- Reduce the risk to the environment (the K-Basin is situated above a hazardous chemical contaminant plume and hinders remediation of the plume until the sludge is removed)

The DOE-RL has stated that "... a key DOE objective is to remove the sludge from the K-West Basin and River Corridor as soon as possible,"1 which will reduce risks to the environment, allow for remediation of contaminated areas underlying the basins, and support closure of the 100-KR-4 operable unit.

The environmental and nuclear safety risks associated with this sludge have resulted in multiple legal and regulatory remedial action decisions, plans, and commitments that are summarized in Table ES-1 and discussed in more detail in Volume 2, Section 9.

\section{Recommendation}

Retrieve and transport sludge without oxidation to T Plant for interim storage until a new facility located on 200 Area Central Plateau is constructed for sludge treatment and packaging (Alternative 6T)

Basis for Recommendation:

- Expeditiously reduces the nuclear safety risk to the public

- Expeditiously reduces environmental risks by moving sludge safely away from the river, thereby allowing earlier remediation of the contaminant plume beneath the basin

- Earliest possible closure of $100-\mathrm{K}$ operable units as required by environmental and regulatory agreements

- Does not preclude decision on ultimate disposition of the waste and preserves the option to combine treatment with other required facilities at Hanford

- Avoids installation and operation of sludge treatment and packaging systems within the difficult operating environment of $\mathrm{K}$ West Basin

- Lowest near-term cost while not resulting in any increase in long-term life-cycle cost

- At least five to nine years quicker for removal of sludge from the Columbia River corridor than any alternative that immobilizes the waste at or near the basin

\footnotetext{
${ }^{1}$ Contract No. DE-AC06-96RL13200 - K Basin Sludge Disposition Direction, letter 08-AMCP-0151 dated March 28, 2008 from L. K. Jarnagin, Contracting Officer, DOE-RL Office to C. M. Murphy, President and Chief Executive Officer, Fluor Hanford Inc.
} 
Table ES-1. K Basin Sludge Related

\section{Remedial Action Decisions, Plans and Commitment Documents}

\begin{tabular}{|l|l|}
\hline $\begin{array}{l}\text { National Environmental } \\
\text { Policy Act }\end{array}$ & $\begin{array}{l}\text { DOE/EIS-0245F, Jan 1996, Management of Spent Nuclear Fuel from the K Basins at } \\
\text { the Hanford Site, Richland Washington and associated Record of Decision (ROD) } \\
\text { (NEblished in Federal Register Vol. 61, page 10736, and DOE/EIS-0245/SA1, Aug 1998, } \\
\text { Supplement Analysis of Environmental Effect of Changes in DOE's Preferred } \\
\text { Alternative for Management of Spent Nuclear Fuel, which include the following } \\
\text { statement: "Remove sludge from the K Basins...." }\end{array}$ \\
\hline $\begin{array}{l}\text { Comprehensive } \\
\text { Environmental Response, } \\
\text { Liability Act }\end{array}$ & $\begin{array}{l}\text { DOE/RL-98-66, Rev. 0, Focused Feasibility Study for the K Basins Interim Remedial } \\
\text { Action, which states, in part that “... sludge will be transferred to a permitted storage }\end{array}$ \\
(CERCLA) & $\begin{array}{l}\text { In 2005 DOE issued an amended CERCLA ROD, which states, in part that "Amended } \\
\text { remedy (sludge) - Sludge will be treated and packaged for disposal and shipped off } \\
\text { Hanford to a national repository." }\end{array}$ \\
\hline Federal Consent Order & $\begin{array}{l}\text { Hanford Federal Facility Compliance Agreement and Consent Order 89-10, (Tri-Party } \\
\text { Agreement), Milestones M-34-00A, "Complete Removal of the K Basins and Their } \\
\text { Content. NOTE: Unless otherwise noted, the term "K Basins" is used to denote both K } \\
\text { East and K West Basins." }\end{array}$ \\
\hline $\begin{array}{l}\text { Defense Nuclear Facility } \\
\text { Safety Board (DNFSB) } \\
\text { Recommendation }\end{array}$ & $\begin{array}{l}\text { Letter, John Conway, Chairman, Defense Nuclear Facilities Safety Board to Honorable } \\
\text { Bill Richardson, Secretary of Energy, dated January 14, 2000, which enclosed } \\
\text { Recommendation 2000-1, Stabilization and Storage of Nuclear Materials (this includes } \\
\text { the K-Basin sludge). }\end{array}$ \\
$\begin{array}{l}\text { Letter, Spencer Abraham, Secretary of Energy, to Honorable John T. Conway, } \\
\text { Chairman, Defense Nuclear Facilities Safety Board dated July 22, 2002, which } \\
\text { referenced Revision 2 of the Department of Energy's Implementation Plan in response } \\
\text { to DNFSB Recommendation 2000-1 }\end{array}$ \\
\hline
\end{tabular}

The purpose of this report is to document the series of alternative analyses and the resultant CH2M HILL Plateau Remediation Company recommendation for the disposition of the majority of the $\mathrm{K}$ Basin sludge. 
Purpose and Scope: In a letter dated March 28, 2008, DOE-RL directed its contractor to " $\ldots$ develop and provide, in accordance with DOE Order 413.3A and DOE Draft Standard 1189, (later issued as DOE-STD-1189-2008) a Critical Decision (CD) - 1 package that includes alternative analyses for removal of the sludge contained in the K West Basin Engineered Containers, settler tanks, and knock-out pots." ${ }^{2}$ (Emphasis and parentheses added.) Later direction removed knock-out pots from the scope of this alternatives analysis. The purpose of this report is to document the series of alternative analyses and the resultant CH2M HILL Plateau Remediation Company (CHPRC) recommendation for the disposition of the majority of the sludge in accordance with the direction from DOE-RL.

This report is organized into two volumes. Volume 1 contains a summary of the analyses and the CHPRC recommendation. Volume 2 contains the details of the analyses, which provide the bases for the summary and the recommendation.

Process: Section 3 of this report describes the process used to identify the wide range of viable options and reduce these to the three alternatives that form the basis for this down-selection activity. Thousands of options were identified that included permutations on processing steps, which technology to use for each processing step, and which pathway to utilize for disposal. The options were screened to eliminate duplications. The initial screening reduced the options to about 700 . These 700 options were then evaluated using a simplified risk and feasibility evaluation methodology, similar options were grouped into the same alternative, and the options were thereby reduced to seven alternatives. An independent group of experts was asked to review the 700 options, the reduction to seven alternatives, and the analysis of the seven alternatives.

Down selection from seven alternatives to three alternatives was done after consideration of hazards (not a discriminator between any of the seven), life-cycle cost (not a discriminator between any of the seven) and schedule (three alternatives had a clear schedule advantage for removal of sludge from the River Corridor). This resulted in the selection of three primary alternatives for a more detailed analysis. Data was produced to allow evaluation of the three remaining alternatives using criteria associated with the following:

1. Safety

2. Regulatory/stakeholder acceptance

3. Technical maturity

4. Operability and maintainability

5. Programmatic considerations

The criteria used for this evaluation are discussed in Section 3.3, and the data developed in support of this evaluation (the data used to down select from thousands to one preferred

\footnotetext{
${ }^{2}$ Ibid 1
} 
alternative) are documented in Volume 2 of this report. In general, a more detailed analysis was performed at each step in the down selection of options to alternatives to preferred alternative. During this analysis, it became apparent that the activities under these alternatives and the associated recommendation for down selection could be split into two logical phases: Phase 1 includes all activities necessary to remove the sludge from the River Corridor and place the sludge in interim storage on the 200 Area Central Plateau. Phase 2 includes all activities necessary to treat and package the sludge for transport to a national repository. In November 2008, the data and system descriptions from this detailed evaluation of the three alternatives were rated and ranked by a CHPRC Decision Support Board (DSB) in accordance with a plan ${ }^{3}$ prepared for supporting this decision (i.e., Decision Plan).

\section{There are two phases for the work under these alternatives:}

Phase 1: All activities necessary to remove the sludge from the Columbia River corridor and place the sludge in interim storage

Phase 2: All subsequent activities necessary to remobilize, treat, and package the sludge for transport to a national repository

Recommendation: Three key questions had to be evaluated by the DSB in order to evaluate the three primary alternatives (see section 4 for more details):

1. Should the metallic uranium in the sludge be oxidized at the basin (Phase 1) prior to loading for shipment from the basin?

- Conclusion: The benefits of early removal from the River Corridor and basin outweigh the benefit of earlier oxidation.

2. Should the sludge be stored in T Plant or a newly constructed storage facility on the central plateau?

- Conclusion: The nuclear and environmental safety advantages of earlier removal of sludge from the river basin outweigh the uncertainty in T Plant suitability. Storage costs are also lower for T Plant, unless Phase 2 is delayed significantly (because the minimum safe operating cost for $\mathrm{T}$ Plant would be greater than the minimum safe operating cost for a new facility). CHPRC and DOE should perform further evaluations of the suitability of T Plant early in the project schedule (see Sections 5 and 6 for more details) to further reduce risk.

3. Is it necessary to commit to the ultimate treatment process at this time?

- Conclusion: Commitment to final treatment technology is not required until Phase 2; this allows adequate time to develop and establish robust treatment and immobilization technologies and resolve any outstanding disposal pathway issues.

\footnotetext{
${ }^{3}$ A21C-STP-WP-0002, October 2008, Sludge Treatment Project: Plan for Selecting the Preferred Alternative for Disposition of Engineered Container and Settler Tank Sludge from $K$ Basins, CH2M HILL Plateau Remediation Company, Richland Washington
} 
After careful consideration of the data as applied to the three alternatives (each with an option to use T Plant or a new interim storage facility), a rating number of one to five (five being the best) was assigned by the DSB to the evaluation criteria for each alternative. A consensus of the DSB was achieved for each criteria rating. Each rating was multiplied by the weights (set in advance in the Decision Plan) for each criterion to achieve a weighted score for each alternative. The total ranked scores are displayed in Figure ES-1. From the rating and ranking process, one alternative was determined to be significantly better than all other alternatives.

Figure ES-1 Alternatives Ranking Scores

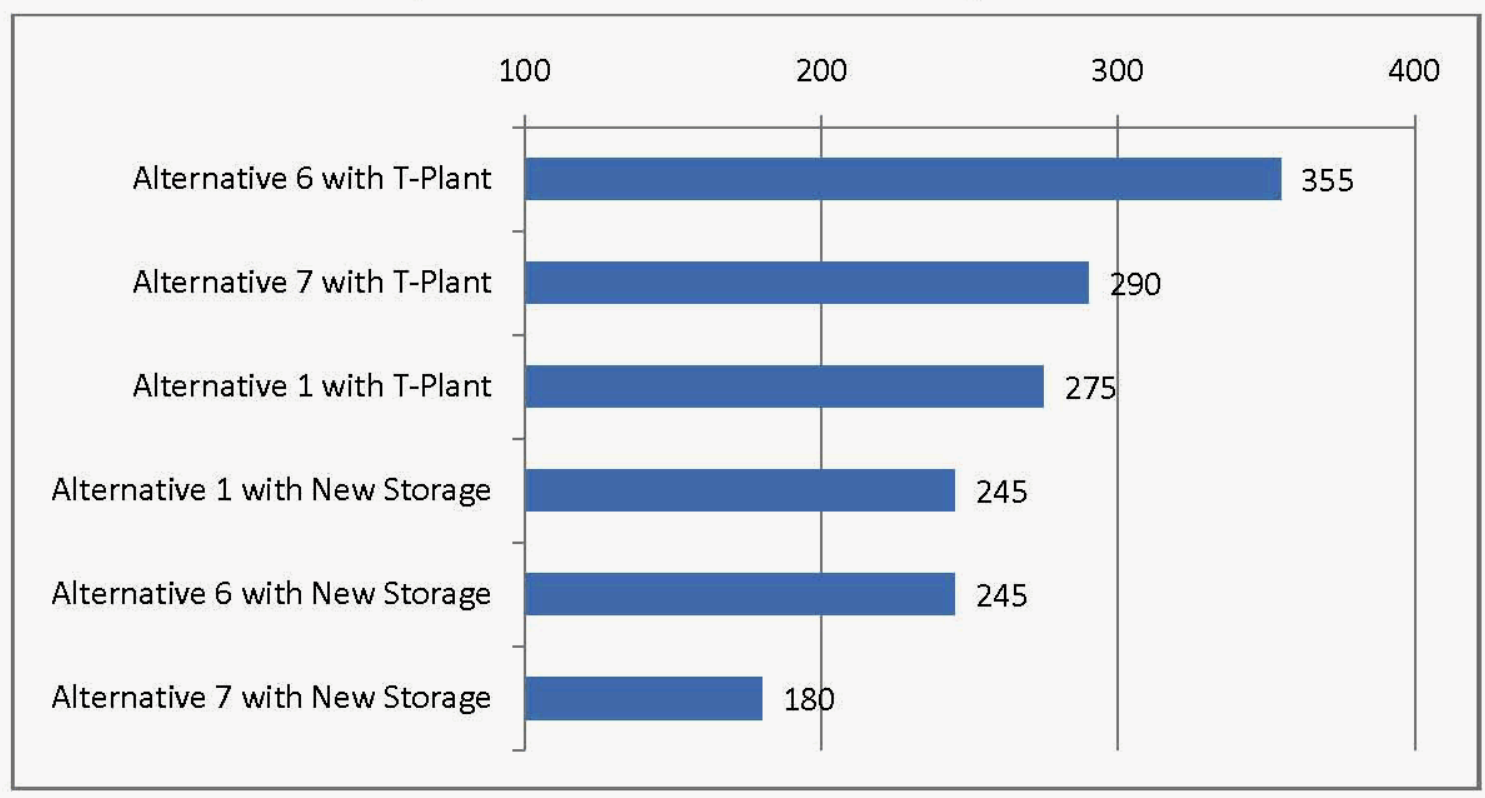

The DSB then performed a sensitivity analysis to determine if changes in the weighting of the criteria, or even elimination of some criteria, would change the results. The same alternative was ranked number one for each case. The second- and third-place alternatives did change depending on the weights applied to the rating criteria. See Section 5 for more details.

Options and alternatives have been vetted as discussed in Sections 3 and 4, and an alternative has been recommended that best meets short- and long-term mission needs at Hanford. Based on the extensive review of past studies and available data, and based on inputs from the Independent Review Committee, the DSB, and CHPRC management reviews, the recommendation of the CHPRC is as follows:

Retrieve and transport sludge without oxidation to $\mathrm{T}$ Plant for interim storage until a new facility located on 200 Area Central Plateau is constructed for sludge treatment and packaging (Alternative 6T). 
Basis: The basis for this recommendation is as follows:

- Expeditiously reduces the nuclear safety risk to the public

- Expeditiously reduces environmental risks

- Supports the earliest closure of $100-\mathrm{K}$ operable units as required by environmental and regulatory agreements

- Reduces worker exposure based on ALARA reviews compared to treatment at the basin (exposure due to oxidation in a hot cell during Phase 2 [Alternative 6] is less than exposure due to oxidation operations at the basin during Phase 1 [Alternative 1])

- Does not preclude a future decision on ultimate disposition of the waste

- Has the lowest near-term cost while not resulting in any increase in long-term life-cycle cost

- Five to nine years quicker for removal of sludge away from the Columbia River than any alternative that immobilizes the waste at or near the basin

Path Forward (actions to implement the recommendation): The CHPRC has developed a list of risks and potential obstacles to implement the recommendation, including the recommended actions to mitigate these risks. These risk mitigation actions, plus other items needed to implement the recommendation, are included in Section 5. Mitigation of remaining risks will be incorporated into the Sludge Treatment Project (STP) risk management plan. Section 6 includes the CHPRC recommended "path forward." Immediate actions (critical path or near critical path actions) to implement the Phase lactivities include:

- Evaluate the suitability (including the seismic design category and necessary modifications) of T Plant with comparison to a new storage facility.

- Perform pre-conceptual design and testing (if necessary) associated with:

- Sludge Retrieval: Evaluate and test technologies (double diaphragm pump system and eductor system) for retrieving sludge from engineered containers and select preferred technology for incorporation into conceptual design.

- Sludge Transport: Evaluate and test technologies (hydraulic and auger) for sludge transfer within the basin and select preferred technology for incorporation into conceptual design.

- $\quad$ TTSC Loading and Unloading: Evaluate and test technologies for loading and unloading (a phase 2 activity, but testing and selection is a phase 1 activity) of an STSC and select preferred technologies for incorporation into conceptual design.

- Reducing the dispersable nature of sludge: Evaluate methods for reducing the airborne dispersibility of sludge including as necessary reversible interim immobilization of sludge. If successful, these technologies could reduce consequences of potential accidents.

- Reduce hydrogen generation: Evaluate methods for reducing the hydrogen release from the sludge during transportation and storage

- Revise the project documents to reflect the two-phase strategy discussed above. 


\subsection{Introduction}

The U. S. Department of Energy (DOE), U. S. Environmental Protection Agency, Defense Nuclear Facility Safety Board (DNFSB), and other regulatory and stakeholder groups have long recognized that the sludge accumulated in the K East and $\mathrm{K}$ West Basins represents an ongoing risk to the public, the worker, and the environment. The sludge is in an easily dispersible form and contains transuranic elements as well as fission products and metals (e.g., aluminum, iron, uranium). Actions taken thus far to mitigate these risks include removing the fuel from the basins and consolidating the sludge from the floors, pits, and fuel canisters formerly stored in the $\mathrm{K}$ East and $\mathrm{K}$ West Basins into three waste streams that are stored in the K West Basin. Sludge is currently stored within Engineered Containers, Settler Tanks, and Knock-Out Pots (KOP) designed to contain this sludge. The next step is to retrieve and package the sludge from the Engineered Containers and Settler Tanks into a waste form suitable for disposal as remote-handled transuranic (RH-TRU) waste at the Waste Isolation Pilot Plant (WIPP).

The U. S. Department of Energy Richland Operations Office (DOE-RL) provided direction to its contractor to develop and evaluate alternatives for the removal of the sludge contained in the $\mathrm{K}$ West Basin. The following direction from DOE-RL ${ }^{4}$ was used by the CHPRC STP during the development and evaluation of alternatives for the removal of the sludge contained in the $\mathrm{K}$ West Basin:

- "... a key DOE objective is to remove the sludge from the K West Basin and River Corridor as soon as possible ...".

- "... The STP is to develop and provide, in accordance with DOE Order 413.3A and DOE Draft Standard 1189, a Critical Decision (CD)-1 package that includes alternatives analyses for the removal of the sludge contained in the K West Basin Engineered Containers, settler tubes, and knock-out pots (KOP)."

\section{The Need for Action}

- K Basin sludge is an ongoing risk to the public, the worker, and the environment

Sludge is in an easily dispersible form

- A key DOE objective is to remove the sludge from the $\mathrm{K}$ West Basin and River Corridor as soon as possible

- DOE-RL directed Alternatives Analyses for removal of sludge from K West Basin:

Alternatives Analysis conducted in accordance with DOE Order 413.3A and DOE Draft Standard 1189

- No schedule, sludge treatment, or packaging constraints applied to Alternative Analysis

\footnotetext{
${ }^{4}$ Contract No. DE-AC06-96RL13200 - K Basin Sludge Disposition Direction, letter 08-AMCP-0151 dated March 28, 2008 from L. K. Jarnagin, Contracting Officer, U. S. Department of Energy Richland Operations Office to C. M. Murphy, President and Chief Executive Officer, Fluor Hanford Inc.
} 
(Note: Subsequent direction from DOE removed the KOP sludge from consideration in this Alternatives Analysis ${ }^{5}$.)

- "... consider moving the sludge with and without treatment to the Central Plateau."

- "Additional criteria which shall be used to evaluate the alternatives are: full lifecycle cost and schedule; project funding profile, technical risk (technology readiness); ALARA and personnel safety; overall project execution risk. Life-cycle costs will include treatment of the sludge even if moved to the Central Plateau prior to treatment."

- In addition to the DOE-RL direction received on March 28, 2008, DOE-RL personnel provided additional guidance for use in the Alternatives Analysis, as documented in Volume 2, Appendix A:

- The project is not constrained to treatment and packaging in the $100 \mathrm{~K}$ Area on the Hanford Site. Options could include treatment at a location other than $100 \mathrm{~K}$ Area.

- Decisions would be weighted toward supporting the DOE objective to remove the sludge from K West Basin and the River Corridor as soon as possible. One-year acceleration in removing sludge from $\mathrm{K}$ West Basin was the initial guidance as a discriminator to move treatment and packaging operations away from $100 \mathrm{~K}$ Area.

- Current sludge-related TPA milestones and DNFSB commitments that are known to be unachievable and discussed in advance with EPA and DNFSB, will not constrain the alternatives analysis.

Additionally, the Engineered Container and Settler Tank sludge waste streams must be processed as separate RH-TRU waste streams to meet WIPP waste stream certification requirements.

Decisions would be weighted toward supporting the DOE objective to remove the sludge from $\mathrm{K}$ West Basin and the River Corridor as soon as possible. One-year acceleration in removing sludge from $\mathrm{K}$ West Basin was the initial guidance as a discriminator to move treatment and packaging operations away from $100 \mathrm{~K}$ Area.

This report contains the CHPRC results from development and evaluation of alternatives for the removal of the Container and Settler Tanks sludge contained in the K West Basin. Section 2 provides information on the origin, characteristics, and physical locations of $\mathrm{K}$ Basin sludge. Section 3 discusses the process used to identify and evaluate alternatives for removal of the sludge contained in the $\mathrm{K}$ West Basin. The alternatives evaluation process resulted in the identification of three alternatives that were further analyzed using identified decision criteria by a Decision Support Board (DSB) chartered by the CHPRC. The rating and ranking of these three alternatives by the DSB is presented in Section 4 along with recommendations by the DSB for implementation of a single alternative. Section 5 provides the CHPRC recommendations, and Section 6 contains the CHPRC implementation plan ("path forward") for the removal of the sludge contained in the K West Basin.

\footnotetext{
${ }^{5}$ E-mail "KOP Changes", dated August 12, 2008 from Mr. T. K. Teynor, DOE-RL Assistant Manager for the River Corridor to Mr. M. W. Johnson, CHPRC Sludge Treatment Project manager
} 


\subsection{Sludge Background and History}

The origin, characteristics, and physical locations of $\mathrm{K}$ Basin sludge are discussed in this section. Section 2.1 provides information on the operating history of the $\mathrm{K}$ Basins, the activities that generated sludge, and the sludge consolidation into the $\mathrm{K}$ West Basin. Section 2.2 discusses sludge characterization and critical characteristics used in the alternatives analysis.

\subsection{Sludge Generation}

The K East and K West reactor basins, shown in Figure 2-1, were constructed in the early 1950 s to support the reactor operations. After irradiation, fuel was pushed from the reactors into the discharge chutes and then sorted, canned, and cued underwater in the basins. This resulted in decay of radionuclides with short half-lives prior to reprocessing at either the 202-S Reduction-Oxidation (REDOX) or the 202A Plutonium Uranium Extraction (PUREX) facilities for plutonium and uranium recovery. The basins originally had a 20 -year design life and were deactivated when the $\mathrm{K}$ West and $\mathrm{K}$ East reactors were shut down. They were placed in long-term standby in February 1970 and January 1971, respectively.

\section{Figure 2-1 Schematic Overview of $\mathrm{K}$ Basin}

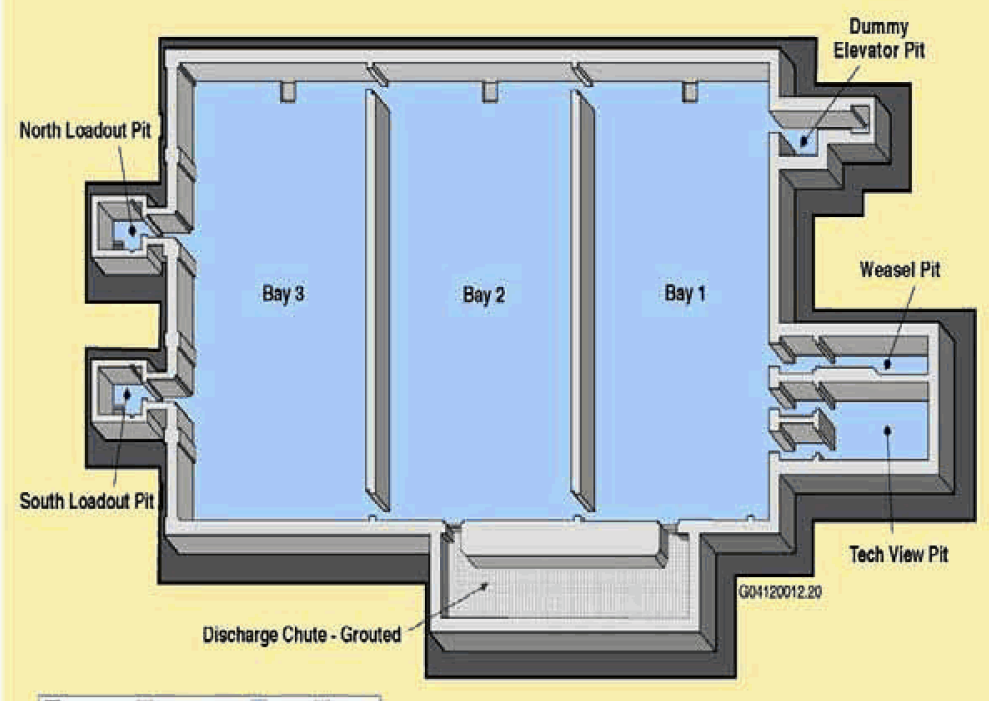

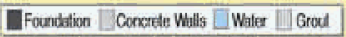

In 1967 , the REDOX reprocessing facility was shutdown. In the early 1970 s, the PUREX reprocessing facility was placed on standby while the $\mathrm{N}$ Reactor continued to operate with a dual-purpose mission - to produce fuels-grade plutonium and

\section{Sludge Properties}

- Sludge is defined as any basin material that will pass through a screen with 0.25 -inch openings

- Sludge is mixture of:

○. SNF corrosion products

- Metallic uranium

- Fuel cladding

- Fission products and actinides $(-300,000$ curies)

- Iron, aluminum and uranium hydroxides

0 Ion exchange resins, PCB contaminated materials, paint chips, spalled concrete; sand, dirt, and organic matter

- Measured $23.5 \mathrm{~m}^{3}$ of KE and $\mathrm{KW}$ floor and pit sludge consolidated into five Engineered Containers

- Estimated TRU content is $3.79 \mathrm{E}+04 \eta \mathrm{Ci} / \mathrm{g}$

- Estimated $5.4 \mathrm{~m}^{3}$ of sludge from fuel washing collected in ten Settler Tanks

- Estimated TRU content is $2.04 \mathrm{E}+05 \eta \mathrm{Ci} / \mathrm{g}$

- Sludge samples obtained prior to consolidation were analyzed to determine chemical and physical properties

- Sludge characterization data is adequate to support alternatives analysis 
electricity. Spent fuel storage at N Reactor filled up so the K East Basin was reactivated in 1975. The K West Basin was reactivated in 1981 as supplemental storage for irradiated N Reactor fuel. The fuel stored in the K East Basin was contained in open-topped canisters, many of which had screened or perforated bottoms. The fuel stored in the K West Basin was contained in closed and sealed canisters.

The PUREX reprocessing facility was operated again from 1983 through 1990 and processed much of the N Reactor fuel that contained weapons-grade plutonium. When a U.S. government policy decision was made in the early 1990 s to stop recovery of plutonium, some 2,300 metric tons (MT) of irradiated fuel remained in storage in the K East and K West basins. This inventory was irradiated uranium metal fuel, some of which was aluminum clad and the majority of which was Zircaloy clad.

Some of the fuel ${ }^{6}$ suffered cladding damage or breaches during reactor operation, primarily during discharge and handling. This provided a pathway for water contact of the fuel and, eventually, corrosion of the metallic uranium fuel. Over time, well beyond the design basis of the fuel (approximately 20 years for K East and 15 years for K West), significant fuel element corrosion occurred and the resulting corrosion products escaped from the canisters to the floor, similar to that shown in Figure 2-2. The basin superstructures are not sealed from the environment, which allowed sand, dirt, and organic material (weeds, bugs, etc.) to be deposited in the basins. Normal and off-normal basin operations contributed spent ion exchange resins and other detritus like spalled concrete and sand filter material; polychlorinated biphenyls (PCB)-bearing materials ${ }^{7}$; and hydroxides of iron, aluminum, and uranium to the sludge accumulation, mostly in the K East Basin. Sludge accumulations in the K West Basin were considerably less due to the sealed fuel storage canisters, better condition of the fuel placed into the basin, better control of the basin water quality, and a prior basin cleanout campaign.

During the years of fuel storage, basin operation periodically required sludge relocation. This often resulted in portions of the sludge being pumped and settled in the various pits adjacent to the main basins. Over time, the sludge became identified by its original deposition location: floor sludge, pit sludge, and canister sludge. The floor and pit sludge in the basins became a nonhomogenous accumulation. By DOE-RL definition, sludge became anything in the basins that would pass through a $1 / 4$-inch screen. Material larger than that has been separated and managed as spent fuel or debris. ${ }^{8}$

\footnotetext{
${ }^{6}$ The $\mathrm{N}$ reactor fuel design was metallic uranium with a Zircaloy cladding

${ }^{7}$ The source of the PCB materials in the basin is unknown per Appendix C of DOE/RL-98-66, 1999, Focused Feasibility Study for the K Basin Interim Remedial Action, U. S. Department of Energy, Richland Washington. Some sludge sample analyses have detected trace levels of PCBs.

${ }^{8}$ Letter dated December 2, 1999 from P.G. Loscoe, DOE-RL/SFO to R.D. Hanson, FH, 00-SFO-043/FH-9958990, "K Basins Sludge Classification".
} 
Figure 2-2 Sludge Escaping from Fuel Storage Canister

In the mid 1990s the decision was made to disposition the fuel stored in the K East and West Basins by packaging it, drying it, and moving it to dry storage on the 200 Area Central Plateau at the Hanford site. There, it would be stored for eventual shipment to the Spent Fuel and HighLevel Waste National Repository. A transport system was designed to move fuel stored in the K East Basin to the West Basin for treatment and packaging. A fuel retrieval system was developed to wash the fuel to remove fuel corrosion products and other material from the fuel prior to packaging. A water treatment system, known as the Integrated Water Treatment System (IWTS), captured material washed from the fuel to maintain the clarity of the basin water. The IWTS is equipped with KOPs and strainers to capture the larger particles (600 micron to $1 / 4$-inch) and a series of settler tubes or tanks (see Figure 2-3) to allow for settling and capture of the finer material ( $<600$ microns) from fuel washing.

During the fuel transfer mission, a number of KOPs were filled and set aside for future processing along with the bulk of the sludge. The KOP sludge material is out of scope for this sludge Alternatives Analysis and will be treated as a separate action by CHPRC. 
HNF-39744, Revision 0, Volume 1 STP ALTE RNATINES ANAIYYSIS SUMMARY REPORT

Figure 2-3 Settler Tanks Captured Sludge Particles Less Than 600 Micron

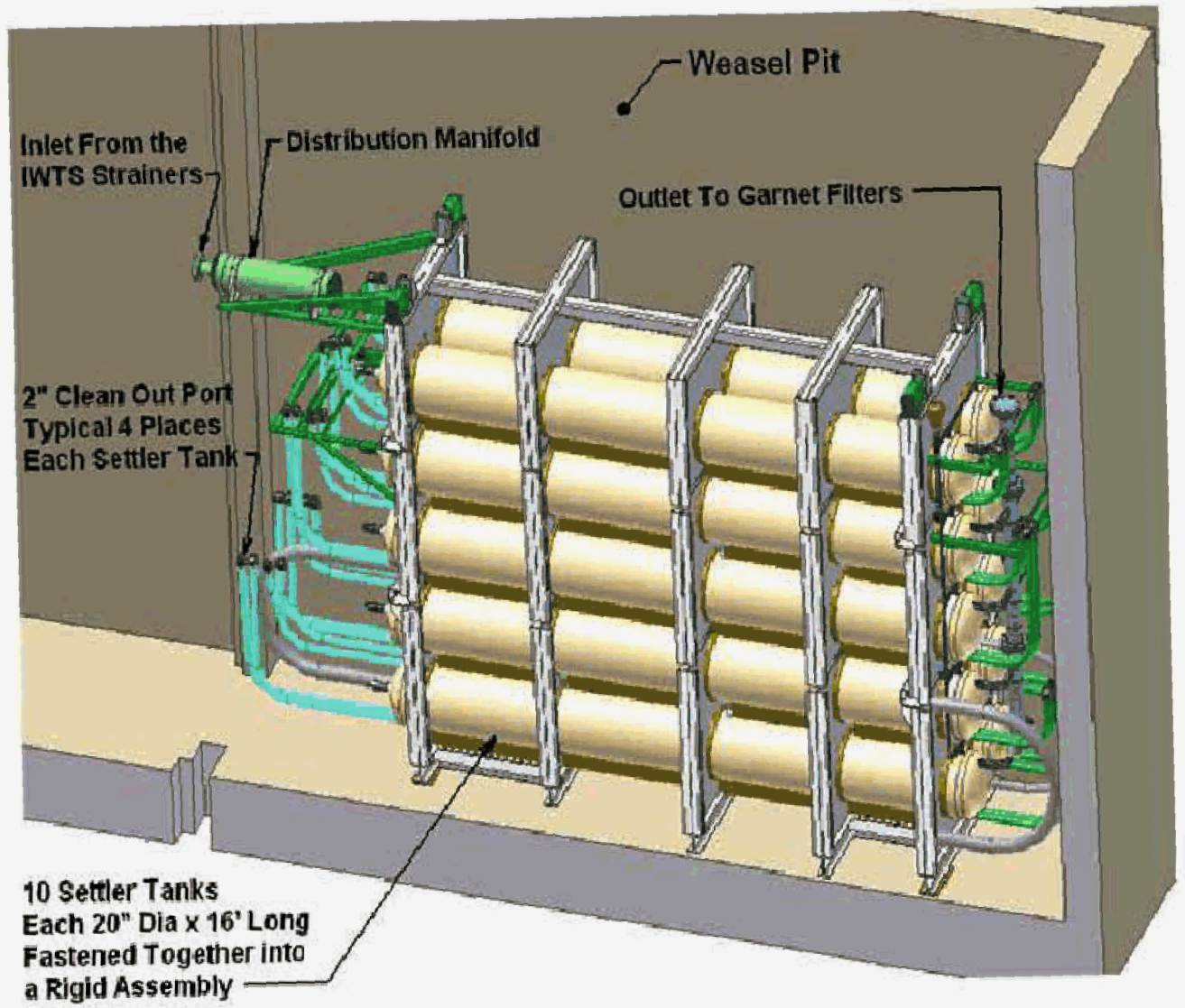




\subsubsection{Sludge Consolidation}

After the fuel was transferred from the $\mathrm{K}$ East Basin to the K West Basin from November 2002 to July 2004, four Engineered Containers were installed in the K East Basin to collect and consolidate most of the K East Basin sludge, which was completed in 2006. In June 2004, approximately $3.5 \mathrm{~m}^{3}$ of sludge from the K East North Load-out Pit was determined to be contact-handled transuranic (CH-TRU) waste. It was transported directly to T Plant, then grouted and packaged into approximately 300 drums for disposal. The remaining collected sludge was then hydraulically transferred beginning in October 2006 from the K East Basin to three out of six Engineered Containers (see Figure 2-4) located in the fuel bays of the West Basin. Removal of all sludge from the $\mathrm{K}$ East Basin was completed in June 2007, which allowed basin decommissioning to begin.

Sludge retrieved from the K West Basin floor and in the pits was transferred into two empty Engineered Containers in the $\mathrm{K}$ West Basin, which was completed in July 2007. It is maintained separate from the K East Basin sludge pending sampling and characterization. A sixth container is being reserved to receive the Settler Tank sludge so that it too, may be sampled and characterized. Sludge within the scope of this Alternatives Analysis is, or will be, consolidated into the Engineered Containers in the K West Basin.

Sludge from the K East Basin and from the floor and pits of the K West Basin is referred to as Container sludge. Sludge still in the Settler Tanks is referred to as Settler Sludge. The estimated total inventory of sludge currently in the K West Basin Engineered Containers is $\sim 23 \mathrm{~m}^{3}\left(\sim 18 \mathrm{~m}^{3}\right.$ from the $\mathrm{K}$ East Basin floor and pits, and $\sim 5 \mathrm{~m}^{3}$ from the $\mathrm{K}$ West Basin floor and pits). Approximately $5.4 \mathrm{~m}^{3}$ of sludge are stored in the Settler Tanks.
All Sludge Consolidated into $\mathrm{K}$ West Basin

- K East Basin sludge collected into four engineered containers and hydraulically transferred to three engineered Containers in K West Basin (June 2007)

- K West Basin sludge consolidated into two engineered containers (July 2007)

- K East and K West basin sludge segregation maintained

- Settler Tank sludge is to be transferred to a separate engineered container in $\mathrm{K}$ West Basin 
Figure 2-4 Engineered Container Used to Consolidate Floor and Pit Sludge

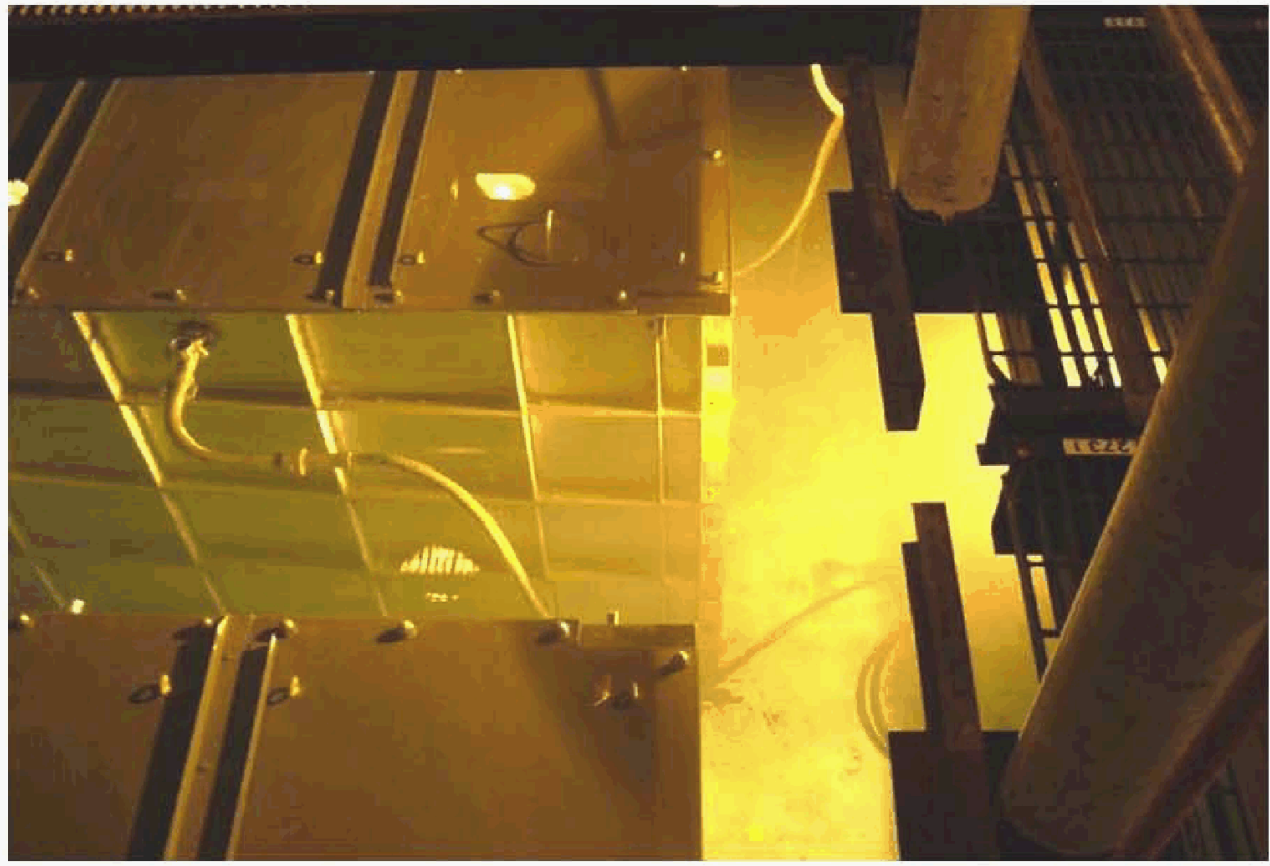

\subsection{Sludge Characteristics}

K Basin sludge has been characterized through sample collection and analysis. ${ }^{9}$ Sludge sampling campaigns have been conducted using the US EPA Data Quality Objectives/Sampling and Analysis Plan methodology ${ }^{10}$. A total of about 32 liters of wet sludge has been collected in 68 samples. Sludge characterization is based on samples taken in the K East Basin prior to Spent Nuclear Fuel processing and sludge recovery/consolidation activities. The sludge critical characteristics used in the alternatives analysis are summarized in Table 2-1. Additional sampling is planned to support nuclear material accountability and to provide confirmatory analysis for process development and design.

Baseline sludge properties have been determined from characterization analyses, in addition to fuel and sludge operations process records. The data is adequate to support this Alternatives Analysis and recommendations.

\footnotetext{
${ }^{9}$ Sludge characterization results are summarized in HNF-SD-SNF-TI-015, revision 13A, Volume 2, Spent Nuclear Fuel Project Technical Databook Vol. 2, Sludge, Fluor, Richland Washington

${ }^{10}$ An example of the data quality objectives methodology applied to the $\mathrm{K}$ Basin sludge sampling and analyses is provided in WIC-SD-SNF-DQO-008, revision 0B, April 2000, Data Quality Objectives for K East Basin Canister Shdge Sampling, Fluor Hanford, Richland Washington
} 
HNF-39744, Revision 0, Volume 1

STP ALTERNATIVES ANALYSIS SUMMARY REPORT

Table 2-1. Slud ge Critical Characteristics

\begin{tabular}{|l|c|c|}
\hline \multicolumn{1}{|c|}{ Characteristic } & Container & Settler \\
\hline Volume $\left(\mathrm{m}^{3}\right)$ & 23.5 & 5.4 \\
\hline Wet Density $\left(\mathrm{g} / \mathrm{cm}^{3}\right)$ & 1.47 & 3.0 \\
\hline Volume Fraction Water & 0.75 & 0.65 \\
\hline Settled Sludge $($ Metric Tons) & 34.5 & 16.2 \\
\hline Uranium (Metric Tons) & 3.415 & 10.260 \\
\hline Uranium Total $\left(\mathrm{g} / \mathrm{cm}^{3}\right)$ & 0.15 & 1.9 \\
\hline Wt $\%$ U total-per $\mathrm{cm}^{3}$ & 9.9 & 63.3 \\
\hline $\mathrm{U}$ metal $\left(\mathrm{g} / \mathrm{cm}^{3}\right)$ & 0.0114 & 0.063 \\
\hline $\mathrm{U}$ metal Total $(\mathrm{kgs})$ & 267.9 & 340.2 \\
\hline Wt $\%$ U metal-per cm ${ }^{3}$ & 0.78 & 2.1 \\
\hline TRU $\left(\mathrm{nCi} / \mathrm{cm}^{3}\right)$ & $5.56 \mathrm{E}+04$ & $6.11 \mathrm{E}+05$ \\
\hline TRU $(\mathrm{nCi} / \mathrm{g})$ & $3.79 \mathrm{E}+04$ & $2.04 \mathrm{E}+05$ \\
\hline FGE $/ \mathrm{m}^{3}$ & $1.20 \mathrm{E}+03$ & $1.38 \mathrm{E}+04$ \\
\hline Decay power $\left(\mathrm{W} / \mathrm{m}^{3}\right)$ & $6.38 \mathrm{E}+00$ & $8.72 \mathrm{E}+01$ \\
\hline OIER Volume $\left(\mathrm{m}^{3}\right)$ & 1.4 & NA \\
\hline OIER $(\mathrm{kgs})$ & $1.67 \mathrm{E}+03$ & NA \\
\hline
\end{tabular}

FGE - Fissile Grams Equivalent

OIER - Organic Ion Exchange Resin

NA - not applicable

The composition of the sludge in the engineered containers is primarily iron and aluminum oxides, concrete grit, sand, dirt, paint chips, and operational and biological debris. It is contaminated with fuel corrosion products and small fragments of metallic uranium. The sludge in the Settler Tanks ranges in particle size from a few microns to $<600$ microns. It is expected to be primarily uranium corrosion products and fission and activation products, with some remaining metallic uranium. This projected inventory of sludge in the Settler Tanks is based on previous characterization of sludge samples from fuel canisters and observations of ongoing hydrogen gas generation from the stored sludge. Settler Sludge may also contain lesser quantities of iron and aluminum oxides, sand, Grafoil ${ }^{\circledR}$ (graphite gasket material) fragments, concrete grit, dirt, and other operational debris. 


\subsection{Alternatives Analysis Process}

The Alternatives Analysis process used by the STP is summarized in this section and discussed in more detail in Volume 2, Section 3. While thousands of alternatives were initially identified, the analysis process summarized in Section 3.1 was used to reduce these to seven viable alternatives for further evaluation. The intermediate steps taken by the STP alternatives analysis team are discussed in Volume 2, Section 3; and only the substantive steps that lead to the identification of the seven alternatives are discussed in Section 3.1. Section 3.2 describes the STP evaluation of these seven alternatives and the selection of three alternatives for further evaluation by a DSB chartered by the CHPRC. Section 3.3 describes the process used by the DSB to recommend a single alternative to the CHPRC.

\subsection{Description of the Alternatives Evaluation Process}

The requirements for processing the $\mathrm{K}$ Basin sludge into a final waste form suitable for transport and disposal at the WIPP are contained in the Transuranic Waste Acceptance Criteria for the Waste Isolation Pilot Plant ${ }^{11}$ and the $R H$ TRAMPAC, revision 0 (June 2006). Requirements in these two documents were used to identify specific requisite processing functions. For example:

- Section 4.10.1 of the WIPP WAC specifies, "Liquid waste is prohibited at WIPP. Residual liquids containing PCBs are prohibited at WIPP. Waste shall contain as little residual liquid as is reasonably achievable by pouring, pumping, and/or aspirating, and internal containers shall contain less than 1 inch or 2.5 centimeters of liquid in the bottom of the container. The total residual liquid in any payload container shall be less than 1 percent by volume of that container." A sludge Packaging function was identified to meet this WIPP WAC requirement.

- Section 5 of the RH-TRAMPAC requires, "hydrogen generated must be limited to a molar quantity that would be no more than $5 \%$ by volume of the innermost layer of confinement (or equivalent limits for other inflammable gases) if present at standard temperature and pressure (i.e., no more than 0.063 gram-moles/cubic foot at 14.7

\section{Alternatives Development}

- Alternatives analysis

conducted in accordance with

DOE Order 413.3A and

direction provided by DOE-RL

- Functions identified to meet

requirements for sludge

processing into a final waste

form suitable for transport and

disposal at WIPP

- Rigorous process used to

identify methods to accomplish

required functions

- Seven alternatives developed from thousands of options

- Down select to three

alternatives based on

evaluation of safety, cost,

schedule, and DOE-RL

guidance

- Alternatives analysis process and down selection reviewed

by Independent Review

Committee

- Decision Support Board rated and ranked remaining three alternatives relative to five selection criteria agreed to by DOE-RL

\footnotetext{
${ }^{11}$ DOE/WIPP-02-3122, revision 6.2, Transuranic Waste Acceptance Criteria for the Waste Isolation Pilot Plant, Effective Date: May 30, 2008, U.S. Department of Energy Carlsbad Field Office
} 
pounds per square inch absolute and $32^{\circ} \mathrm{F}$ )." Section 5 of the RH-TRAMPC also requires, "The gases generated in the payload and released into the RH-TRU 72-B IV cavity shall be controlled to maintain the pressure within the IV cavity below the acceptable design pressure of 150 pounds per square inch gauge." Two sludge functions, Pretreatment and Treatment, were identified for separating and reacting uranium metal prior to placement in the payload container to reduce hydrogen gas generation rate from the final waste form.

In processing the $\mathrm{K}$ Basin sludge into a final waste form suitable for disposal at the WIPP, additional requirements will be applied, including the DOE-RL direction and guidance identified in Section 1.0. However, at this stage of the alternatives analysis, only those requirements that derive specific sludge processing functions were used for evaluating alternatives. Additional functions were identified for sludge mobilization, interim storage, transfer, onsite transportation, off-site transportation, and WIPP Certification and Transport. The complete set of sludge processing functions includes:

- Sludge Mobilization (Retrieval): Process that mobilizes and removes the sludge from the storage containers

- Pretreatment: Process that separates uranium metal from a sludge stream

- Treatment: Process that reacts uranium metal for hydrogen mitigation, regardless of whether pretreatment function is applied

- Interim Storage: Storage of the sludge on the Hanford Site as a slurry prior to packaging

- Sludge Transfer: Process that moves sludge between other identified functions

- Packaging: Process that incorporates sludge into a waste form suitable for disposal at WIPP

- On-site Transportation: Transportation of the sludge slurry or a solid in a container within the confines of the Hanford Site using existing approved casks

- Off-site Transportation: Transportation of the sludge in appropriate form from the Hanford Site to an off-site facility for pretreatment, treatment, and/or packaging using existing approved casks

- WIPP Certification and Transport: Certification that the final waste form package meets WIPP transport and disposal requirements, and transport of the waste package to WIPP

Functions are grouped together to form integrated alternatives for sludge processing. Not all of these functions need be performed by a single alternative. For example, if sludge pretreatment is not performed, then the treatment function processes all of the sludge instead of the uranium metal fraction. Additionally, some or all of these functions can be performed at the K West Basin, at the 200 Area Central Plateau, or at facilities located away from the Hanford Site (i.e., off-site).

This Alternatives Analysis took advantage of the large number of past studies on sludge disposition as a starting point to identify viable technologies, facilities, and transportation methods for accomplishing the required sludge processing functions. These past studies were also one source of the data used in this evaluation. Additionally, new technologies were identified to accomplish these functions. At the initial stage of generating and evaluating 
alternatives, methods were not identified for the sludge mobilization (retrieval), sludge transfer, and WIPP Certification and Transport functions because these functions are common to all alternatives and do not discriminate among alternatives. These functions were included in the alternatives evaluation performed by the CHPRC DSB discussed in Section 3.2.

These technologies, facilities, and transportation methods were then combined into numerous unique alternatives that accomplish the required sludge processing functions. Technologies discussed are representative of technologies that could perform required functions, but no single technology has been selected for each function.

These alternatives were evaluated by the STP engineering team using assumptions and constraints developed by the STP to screen out non-viable methods, as described in Volume 2, Sections 2 and 3. Information generated that assisted in evaluating the alternatives included engineering studies, preliminary life-cycle schedule, and a risk assessment covering 67 elements in seven categories (i.e., safety, programmatic, technical, transportation, regulatory, constructability, and operations and maintenance). Rough order of magnitude (ROM) life-cycle schedules were developed for each of the alternatives. Any alternative with duration greater than 30 years was eliminated from consideration because it would unduly delay remediation of the 100-KR-4 operable unit, which is discussed further in Volume 2, Section 3. If an alternative failed any of the 67 risk elements, it was eliminated. Volume 2 Appendices $\mathrm{N}$ and $\mathrm{O}$ provide a complete list of the 67 risk elements and the ranking of each alternative.

Technologies used in the alternatives analyses are representative but not definitive of technologies that could perform required functions. 
HNF-39744, Revision 0, Volume 1

STP ALTERNATIVES ANALYSIS SUMMARY REPORT

An STP engineering evaluation concluded that each function would be evaluated in the

Alternative Analysis process using the corresponding methods listed in Table 3-1.

\begin{tabular}{|l|l|}
\hline \multicolumn{1}{|c|}{ Table 3-1. Methods used for Functions in Alternatives Analysis } \\
\hline Pretreatment & \multicolumn{1}{c|}{ Methods } \\
\hline Treatment & $\begin{array}{l}\text { Elutriation is representative of the pretreatment function used for alternatives analysis based } \\
\text { on prior testing of this technology using sludge simulants. }\end{array}$ \\
\hline Interim Storage & $\begin{array}{l}\text { Ambient pressure warm-water oxidation or in-drum heating of the packaged sludge to } \\
\text { oxidize the uranium metal is representative of the treatment functions used for alternatives } \\
\text { analysis. These methods were selected based on prior testing of this technology using actual } \\
\text { sludge samples and international data on reaction of uranium metal with water. }\end{array}$ \\
\hline Packaging & $\begin{array}{l}\text { After examining existing available facilities for interim storage of K Basin sludge, T Plant or } \\
\text { a new interim storage facility were identified as the only viable facilities. }\end{array}$ \\
\hline On-site Transportation & $\begin{array}{l}\text { An absorbent, grout, or combination is suitable for mixing with the sludge slurry to meet } \\
\text { WIPP requirements for the final waste form in the 30-gallon drum package. }\end{array}$ \\
\hline $\begin{array}{l}\text { For on-site transportation of packaged sludge, the drum will be placed into a shielded on-site } \\
\text { interim storage container (ISC). The only existing approved casks for onsite transportation of } \\
\text { large (i.e., approximately 2 m }{ }^{3} \text { ) of sludge as a slurry is the Sludge Transport System (STS) } \\
\text { cask. }\end{array}$ \\
\hline Off-site Transportation & $\begin{array}{l}\text { Off-site Transportation of large quantities of sludge as a slurry for off-site processing is not } \\
\text { viable due to the lack of approved shipping containers and casks. Therefore, off-site } \\
\text { transportation and processing methods were eliminated. }\end{array}$ \\
\hline
\end{tabular}

As a result of the alternatives evaluation process conducted by the STP engineering team, the seven unique alternatives listed in Table 3-2 were identified for processing the $\mathrm{K}$ Basin sludge into a final waste form suitable for disposal at the WIPP. Volume 2, section 4 provides further description of these seven alternatives.

\footnotetext{
${ }^{12} \mathrm{HNF}-3132,1998$, K Basin Sludge/Resin Bead Separation Test Report, Rev. 0, D. Squier, Fluor Hanford, Richland Washington

${ }^{13}$ PNNL-17815, 2008, Uranium Metal Reaction Behavior in Water, Sludge, and Grout Matrices, C. H. Delegard and A. J. Schmidt, Pacific Northwest National Laboratory, Richland Washington
} 
HNF-39744, Revision 0, Volume 1

STP ALTERNATIVES ANALYSIS SUMMARY REPORT

\begin{tabular}{|c|c|}
\hline Alternative & Description of Functions \\
\hline 1 & $\begin{array}{l}\text { - Retrieve sludge from Engineered Containers } \\
\text { - Conduct sludge Pretreatment and Treatment in the K West Basin } \\
\text { - Transfer the treated sludge as a slurry in the STS cask to the } 200 \text { Area Central Plateau } \\
\text { - Interim-store the treated sludge in either T Plant or a new facility on the } 200 \text { Area Central Plateau } \\
\text { - } \text { new package the treated sludge into a final waste form (grout or absorbent) suitable for disposal at WIPP in a } \\
\text { - Interim store the packaged sludge until containers are packaged for shipment to WIPP }\end{array}$ \\
\hline 2 & $\begin{array}{l}\text { - Retrieve sludge from Engineered Containers } \\
\text { - } \\
\text { - } \text { Package the treated sludge into a final waste form (grout or absorbent) suitable for disposal at WIPP in a } \\
\text { new packaging facility located at the K Basin } \\
\text { - Transport the packaged sludge in ISCs to the } 200 \text { Area Central Plateau for interim storage in a new facility } \\
\text { - Interim-store the packaged sludge until containers are packaged for shipment to WIPP }\end{array}$ \\
\hline 3 & $\begin{array}{l}\text { - Retrieve sludge from Engineered Containers } \\
\text { - Package the untreated sludge into a final waste form (absorbent) suitable for disposal at WIPP in a new } \\
\text { packaging facility located at the K Basin } \\
\text { - Transport the untreated packaged sludge in ISCs to the } 200 \text { Area Central Plateau for interim storage in a } \\
\text { new facility } \\
\text { - Interim-store the untreated packaged sludge until containers are packaged for shipment to WIPP }\end{array}$ \\
\hline 4 & $\begin{array}{l}\text { - Retrieve sludge from Engineered Containers } \\
\text { - Package the untreated sludge into a final waste form (grout) suitable for disposal at WIPP using new } \\
\text { equipment located underwater at the K Basin } \\
\text { - Transport the packaged sludge in the ISCs to the } 200 \text { Area Central Plateau for interim storage in a new } \\
\text { facility } \\
\text { - Treat the packaged sludge to oxidize uranium metal by heated storage of the waste containers } \\
\text { - Interim-store the treated packaged sludge until containers are packaged for shipment to WIPP }\end{array}$ \\
\hline 5 & $\begin{array}{l}\text { - Retrieve sludge from Engineered Containers } \\
\text { - Package the untreated sludge into a final waste form (grout) suitable for disposal at WIPP using new } \\
\text { equipment located above water at the K Basin } \\
\text { - Transport the packaged sludge in ISCs to the } 200 \text { Area Central Plateau for interim storage in a new facility } \\
\text { - Treat the packaged sludge to oxidize uranium metal by heated storage of the waste containers } \\
\text { - Interim-store the treated packaged sludge until containers are packaged for shipment to WIPP }\end{array}$ \\
\hline 6 & $\begin{array}{l}\text { - Retrieve sludge from Engineered Containers } \\
\text { - Transfer the untreated sludge as a slurry in the STS cask to the } 200 \text { Area Central Plateau } \\
\text { - Interim-store the untreated sludge in either T Plant or a new facility on the } 200 \text { Area Central Plateau } \\
\text { - } \text { Conduct sludge Pretreatment and Treatment in a new facility located on the } 200 \text { Area Central Plateau } \\
\text { new packaging facility located on the } 200 \text { Area Central Plateau } \\
\text { - Interim-store the packaged sludge until containers are packaged for shipment to WIPP }\end{array}$ \\
\hline 7 & $\begin{array}{l}\text { - Retrieve sludge from Engineered Containers } \\
\text { - Transfer the untreated sludge as a slurry in the STS cask to the } 200 \text { Area Central Plateau } \\
\text { - } \text { Interim-store the untreated sludge in either T Plant or a new facility on the } 200 \text { Area Central Plateau } \\
\text { - package the untreated sludge into a final waste form (grout) suitable for disposal at WIPP in a new } \\
\text { - Treat the packaged sludge to oxidize uranium metal by heated storage of the waste containers } \\
\text { - Interim-store the packaged sludge until containers are packaged for shipment to WIPP }\end{array}$ \\
\hline
\end{tabular}




\subsection{Reducing the Number of Alternatives to Three}

These seven alternatives, including the information generated to evaluate these alternatives (see Volume 2, section 5), underwent a rigorous review by an Independent Review Committee (IRC) in September 2008. The minutes of the IRC meetings to review the seven alternatives are included in Volume 2, Appendix Q. The IRC membership and curricula vitae are provided in Volume 2 , Section 10 . The IRC assessed the alternatives development process and the seven selected alternatives. Besides the IRC, the review included representatives from DOE, EPA, DNFSB and WIPP. The IRC concluded that the project had followed a sound process for developing these seven alternatives. The IRC then recommended a ROM life-cycle cost and schedule analysis and a preliminary Hazards Consideration consistent with expectations in DOE STD-1189-2008 for the seven selected alternatives, which the STP engineering team prepared.

The preliminary Hazards Consideration ${ }^{14}$ review included representation from Nuclear and Process Safety, Criticality Safety, Industrial Safety and Hygiene, Radiological Control, Project Engineering, and Fire Protection disciplines and was consistent with the expectations of DOE-STD-1189-2008. This preliminary Hazards Consideration review determined the following:

1. None of the alternatives exhibit a clear, distinct safety advantage.

2. Only safety significant controls are needed (i.e., no safety class controls) for each alternative.

3. There is no unique or unanalyzed hazard associated with any of the seven alternatives.

The schedule analysis focused on the critical path of each alternative to remove sludge away from K Basins and the Columbia River, and is summarized in Figure 3-1. At this point, the seven alternatives were divided into two phases:

1. Movement of sludge from $\mathrm{K}$ Basins and interim storage is Phase 1 of the project.

2. Packaging, storage, and preparation for shipment to WIPP are in Phase 2.

Alternatives 1,6 , and 7 transfer sludge as slurry to the 200 Area Central Plateau prior to packaging. This analysis shows alternatives 1,6 , and 7 remove the sludge from $\mathrm{K}$ West Basin five to nine years faster than Alternatives 2 through 5, which package sludge at the K Basins.

\footnotetext{
${ }^{14}$ KBC-39341, revision 0, 2008, Sludge Treatment Project Pre-Conceptual Alternatives Hazards Consideration, CH2M HILL Plateau Remediation Company, Richland Washington
} 
Alternatives 1,6 , and 7 satisfy the DOE objective to remove the sludge off the River Corridor as soon as possible in comparison to Alternatives 2 thru 5.

Results of the ROM cost analysis show life-cycle costs developed at this stage of the analysis are the same for each alternative within the accuracy of the estimate. However, Phase 1 costs, which are about $1 / 3$ of the estimated ROM life-cycle costs, are significantly lower for Alternatives 1,6 , and 7, because fewer operations occur at $\mathrm{K}$ Basins with these alternatives.

Alternatives 1,6 , and 7 were selected by the STP for further evaluation by the DSB based on the analysis discussed above. The decision to reduce the number of alternatives to be studied further from seven to three is supported by the following:

- Hazards consideration shows no clear advantage or disadvantage for any alternative.

- $\quad$ Phase 1 schedule advantage for Alternatives 1,6 , and 7 with respect to Alternatives 2, 3, 4, and 5.

- Phase 1 cost advantage for Alternatives 1,6, and 7 with respect to Alternatives 2, 3, 4, and 5.

- No advantage or disadvantage in life-cycle cost for any alternative.

- IRC concurred in October 2008 with the down selection to three alternatives and DOE-RL agreed. 
HVF-39744, Revision 0, volume 1

STP ALTERNAT IVES ANAL YSIS SUMMARY REPORT

Figure 3-1 Critical Path Analysis

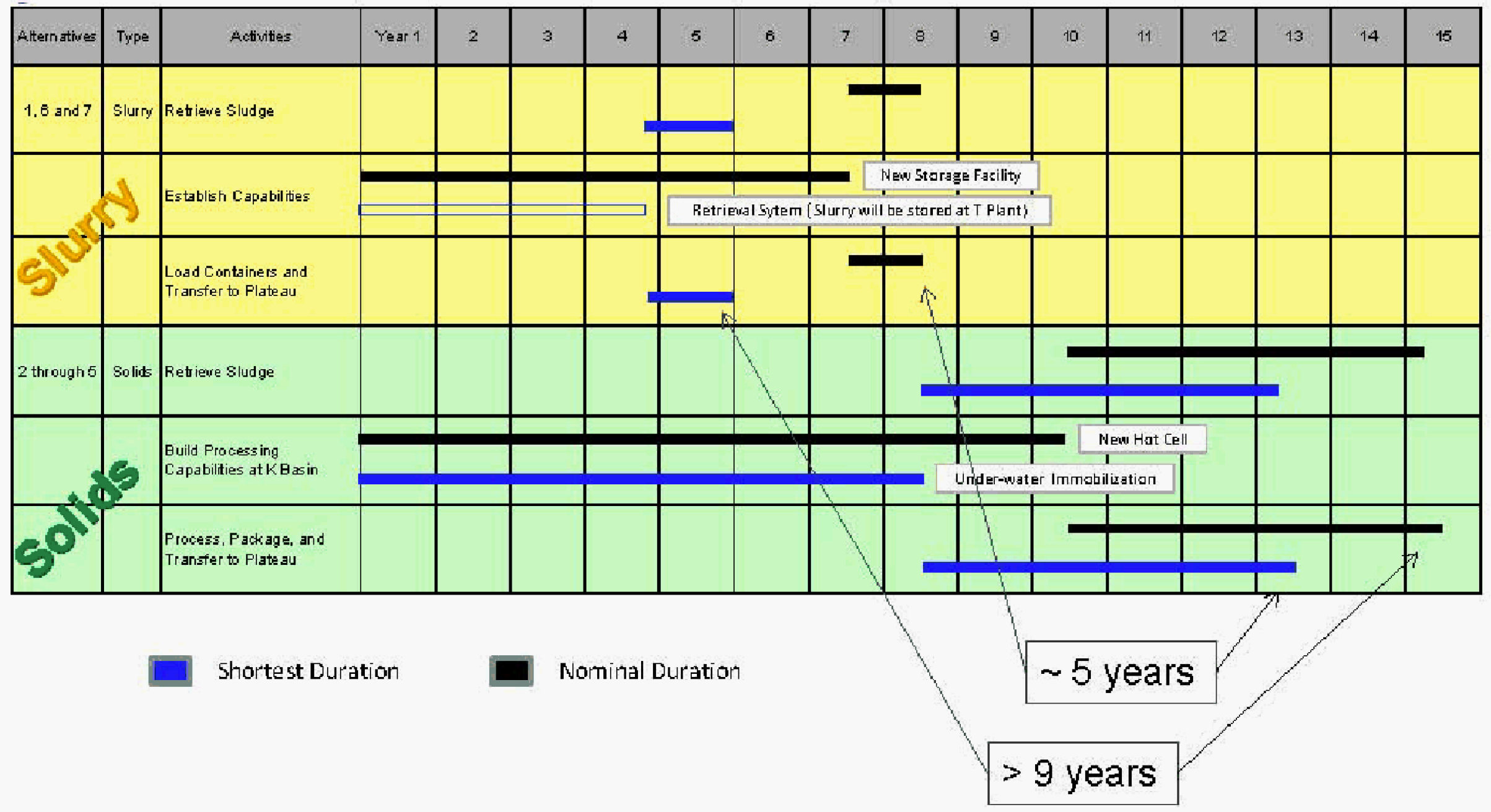




\subsection{Process for Reducing the Number of Alternatives to One}

The DSB was convened to assess Alternatives 1, 6, and 7 and to make a recommendation to the CHPRC regarding which alternative to carry forward as a baseline path for the project. The DSB implemented the requirements of the Decision Plan, ${ }^{15}$ which DOE-RL had previously reviewed and concurred with. Nine experts (see Volume 2, Section 11 for profiles of the DSB members) convened to review concepts for the three alternatives and information developed by the $\mathrm{STP}$ subject matter experts. The alternatives were rated and ranked by consensus of the DSB relative to five selection criteria, as shown in Table 3-3. The weighting, goals, and measures for each criterion from the Decision Plan are described for each criterion in Table 3-3. These criteria, goals, and measures along with the weighting factors were developed jointly with DOE-RL personnel, as discussed in the Decision Plan. A scoring system of 1 through 5, with 5 being the most favorable, was developed to support a multi-variant analysis rating of the three alternatives.

The DSB conducted meetings in Richland Washington from November 17 through November 20, 2008. These meetings included suggestions and opinions of invited observers from DOE-HQ, DOE Carlsbad Field Office, DOE-RL, DNFSB, EPA, operating contractor representative from WIPP, and the STP IRC. The DSB reviewed and discussed information prepared by the STP project team, solicited input from invited observers, rated and ranked the alternatives relative to the five selection criteria, and performed a multi-variant analysis of the alternatives. In addition, the DSB provided comments regarding their opinion of residual risks for the DSB recommended alternative.

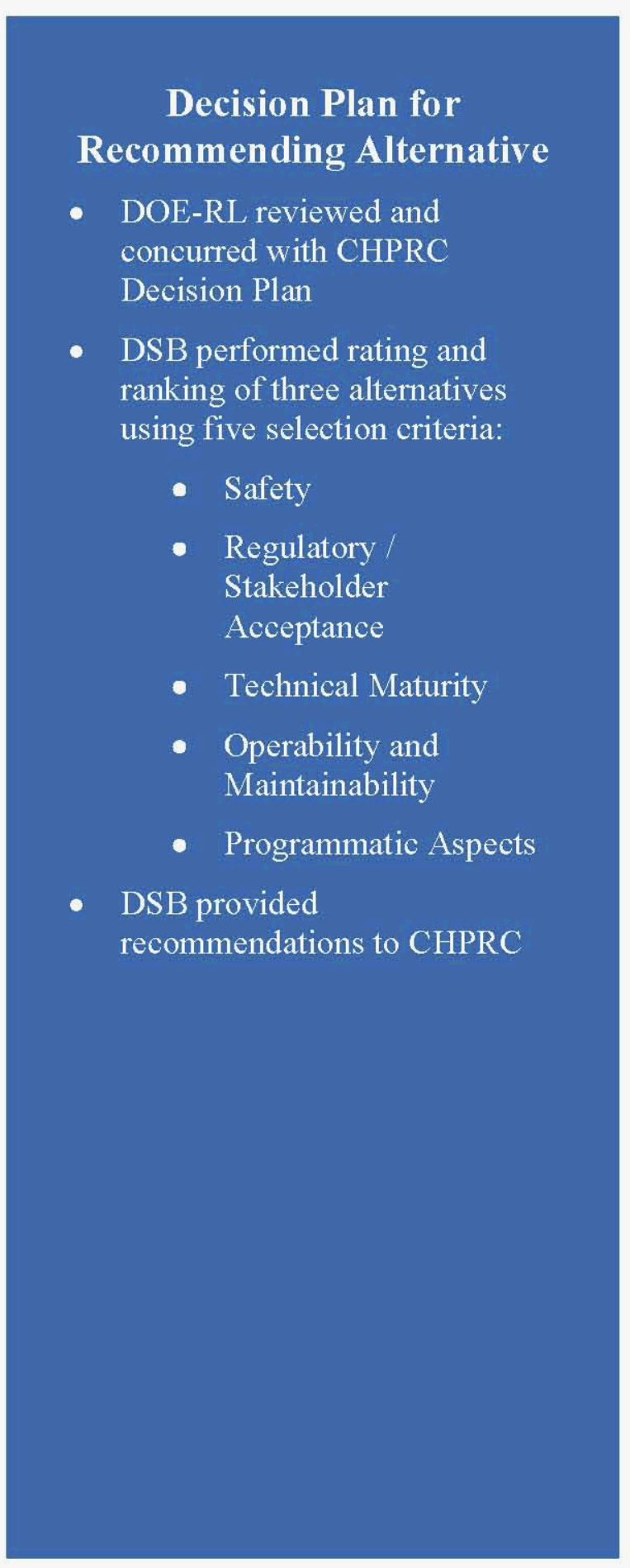

\footnotetext{
15 A21C-STP-WP-0002, October 2008, Sludge Treatment Project: Plan for Selecting the Preferred Alternative for Disposition of Engineered Container and Settler Tank Sludge from $K$ Basins, CH2M HILL Plateau Remediation Company, Richland Washington
} 
HNF-39744, Revision 0, Volume 1

Table 3-3. Criteria, Goals, and Measures

\begin{tabular}{|c|c|c|c|}
\hline Criteria & Weight & Goals & Measures \\
\hline 1. Safety & Go or No-Go & $\begin{array}{l}\text { Ensure worker and Public } \\
\text { Safety }\end{array}$ & $\begin{array}{l}\text { - } \\
\text { - } \\
\text { Criticality Safety } \\
\text { Industrial Safety and Hygiene }\end{array}$ \\
\hline $\begin{array}{l}\text { 2. Regulatory/ } \\
\text { Stakeholder } \\
\text { Acceptance }\end{array}$ & 25 & \begin{tabular}{ll|} 
- Provide environmental \\
compliance \\
Schedule for removing \\
sludge from River \\
Corridor
\end{tabular} & $\begin{array}{l}\text { Number of years before sludge is } \\
\text { removed from River Corridor }\end{array}$ \\
\hline 3. Technical Maturity & 20 & $\begin{array}{l}\text { Maximize confidence } \\
\text { in process } \\
\text { implementation }\end{array}$ & $\begin{array}{l}\text { Technology Readiness Level (TRL) } \\
\text { must be at } 3 \text { or above prior to submittal } \\
\text { for CD-1 } \\
\text { - Process Flexibility and Robustness }\end{array}$ \\
\hline $\begin{array}{l}\text { 4. Operability and } \\
\text { Maintainability }\end{array}$ & 25 & \begin{tabular}{|l|} 
Maximize operability \\
difficulty and \\
maximize safety
\end{tabular} & $\begin{array}{l}\text { - } \\
\text { - } \text { As low as reasonably achievable } \\
\text { (ALARA) } \\
\text { - } \text { Reliability } \\
\text { - Ease and Frequency of Maintenance } \\
\text { - } \\
\text { Liquid/solid secondary waste } \\
\end{array}$ \\
\hline $\begin{array}{l}\text { 5. Programmatic } \\
\text { Aspects }\end{array}$ & 30 & $\begin{array}{l}\text { Minimize overall } \\
\text { system interface } \\
\text { Meet cost and } \\
\text { schedule guidance }\end{array}$ & $\begin{array}{l}\text { Total project cost } \\
\text { - Total life-cycle cost } \\
\text { - Schedule impact } \\
\text { - Impacts to WIPP, Yucca Mountain, } \\
\text { Tank Farms and Waste Treatment Plant } \\
\text { (WTP) - positive and negative } \\
\text { Impacts to other planned activities at } \\
\text { the K Basins and other Hanford } \\
\text { Facilities (e.g., Analytical Laboratory, } \\
\text { canister storage building, T Plant) } \\
\text { Resources and materials }\end{array}$ \\
\hline
\end{tabular}




\subsection{DISCUSSION OF THE SUMMARY DATA}

This section summarizes the data used by the DSB to evaluate the three remaining alternatives and the DSB's recommendations to the CHPRC relating to the single recommended alternative for sludge remedial actions. A more detailed discussion of alternatives identification, analysis, and data is provided in Volume 2, Section 5. A separate report details the DSB deliberations and recommendations ${ }^{16}$. Section 5 discusses the CHPRC recommendations for the Sludge Treatment Project, which considered the information developed by the DSB in formulating recommendations to DOE-RL.

Alternatives 1,6 , and 7 were developed in greater detail by the STP engineering team prior to the DSB rating and ranking of each alternative. Pre-conceptual designs were developed sufficiently to provide supporting information for an Association for the Advancement for Cost Engineering (AACE) Class 4 cost estimate $(-30 \% /+50 \%$ accuracy range on capital costs) and schedule. At this stage of alternatives development, it became necessary to compare interim slurry storage at a new facility with interim slurry storage in $\mathrm{T}$ Plant for each of the three alternatives. Therefore, subalternatives $1 \mathrm{~N}, 1 \mathrm{~T}, 6 \mathrm{~N}, 6 \mathrm{~T}, 7 \mathrm{~N}$, and $7 \mathrm{~T}$ were created, with the "N" designating a new interim storage facility path and the "T" designating a T Plant path. The details of the cost and schedule analysis, with supporting design concepts, are provided in Volume 2, Section 7.

Pre-conceptual development included a number of elements necessary to support cost, schedule, technical maturity, and risk evaluation. Critical Technology Elements (CTEs) were identified for performing the required sludge processing functions, as discussed in Volume 2, Section 6. These CTEs are representative of technologies that could perform the required sludge processing functions, but technology selections were not made. Preliminary process flow diagrams were developed using these CTEs for each alternative, providing a basis for typical major equipment sizing and placement, as well as approximate operating times. Conceptual drawings and high-level process descriptions were produced to provide a basis for design and construction cost estimates. Preliminary technology

\section{Decision Support Board}

Review of Alternatives

- Three alternatives were rated

and ranked in accordance with

five selection criteria in the

CHPRC-approved Decision

Plan:
Safety
Regulatory
Stakeholder Acceptance
Technical Maturity
Operability and
Maintainability
Programmatic Aspects

- The Decision Support Board

unanimously recommended

implementation of

Alternative 6T.

\section{Alternative $6 \mathrm{~T}$ \\ dominant for all five \\ decision criteria; \\ sensitivity analysis did \\ not change results}

- Benefit of early removal of

sludge from the $\mathrm{K}$ West Basin

and River Corridor outweighed

the risk reduction benefit of

earlier oxidation of uranium

metal conducted in

Alternative 1

- Risks / vulnerabilities were

identified with implementation

of recommended alternative

\footnotetext{
${ }^{16}$ A21C-STP-WP-0003, revision 0, 2008, Sludge Treatment Project Decision Support Board Preferred Alternative Workshop, CH2M HILL, Richland Washington
} 
readiness evaluations were performed for each identified CTE, following the guidelines of the DOE Office of Environmental Management's "Technology Readiness Assessment (TRA) / Technology Maturation Plan (TMP) Process Guide" (March 2008). TRL levels developed for CTEs provided input to the DSB as one measure of technical, cost, and schedule risk associated with design and construction of process systems.

Schedule elements included: 1) design and construction activities for K Basin, interim storage facility, and treatment and/or packaging facility, 2) K Basin STP operations, 3) 200 Area Central Plateau operations, 4) WIPP shipping operations, and 5) decommissioning of new sludge treatment and packaging facilities. Decision Plan assumptions were used to support durations for DOE 413.3A design stages.

\subsection{Description of the Alternatives}

To complete removal of sludge from the River Corridor requires the sludge be retrieved from the $\mathrm{K}$ West Basin, packaged as slurry into the sludge transport and storage containers (STSCs) / STS cask, transferred to the 200 Area Central Plateau, and placed into interim storage until a new packaging facility is available. The sludge may or may not be oxidized prior to transfer to the 200 Area Central Plateau. The sludge will be stored in T Plant or a new facility prior to packaging for disposal at WIPP.

Phase 1 activities are those required to remove the sludge from the River Corridor and store sludge on the 200 Area Central Plateau. To prepare the sludge for disposal at WIPP requires that the uranium metal contained in the sludge be oxidized to reduce the hydrogen gas generation rate. The oxidation step may be performed prior to or after the sludge is packaged into drums (i.e., during Phase 1 or Phase 2). During Phase 2, the sludge is packaged into drums that are placed into ISCs. In Phase 2 , the drums are removed from the ISCs and packaged for shipment to WIPP. Grout, absorbent, some other WIPP approved inert filler, or some combination of these may be used for packaging the waste to meet WIPP criteria for residual liquid content and other applicable established functional requirements. Remaining activities to prepare, package, and ship the sludge to WIPP are in Phase 2 .

The three Alternatives for this analysis, 1, 6, and 7 and sub-alternatives " $\mathrm{T}$ " and " $\mathrm{N}$ ", each contain the same primary functions, as shown in Figure 4-1. In Figure 4-1 the activities that are performed at $\mathrm{K}$ Basin are highlighted in yellow, and those activities that are performed on the 200 Area Central Plateau are highlighted in orange. In Figure 4-1, the length of each colored segment does not represent the relative duration for activities. The Phase 1 and Phase 2 activities performed in each alternative are described in Table 4-1.

\section{Figure 4-1 Three Alternatives}

Note: All alternatives include sludge mobilization at front; and store, load, and ship to WIPP at the end

1. Oxidize Underwater, Slurry to Plateau, Grout/Absorbent in Drums

6. Slurry to Plateau, Oxidize Slurry, Grout/Absorbent in Drums

7. Slurry to Plateau, Grout, Oxidize in Drums

K Basin Activity $\square$ Central Plateau Activity 
Table 4-1. Phase 1 and Phase 2 Activities for Each Alternative

\begin{tabular}{|c|c|c|}
\hline Alternative & Phase 1 & Phase 2 \\
\hline 1 & $\begin{array}{l}\text { - } \text { Retrieve sludge from K West Basin. } \\
\text { Oxidize the uranium metal in a new system } \\
\text { installed in the K West Basin using ambient } \\
\text { pressure, warm-water treatment. } \\
\text { Elutriation (gravity separation of lighter } \\
\text { particles by using a vertically directed } \\
\text { liquid flow) can optionally be performed on } \\
\text { the Container Sludge waste stream prior to } \\
\text { oxidation to separate the small fraction } \\
\text { (less than } 20 \% \text { ) of material containing } \\
\text { uranium metal from the larger fraction not } \\
\text { requiring oxidation. } \\
\text { Package and transport to the } 200 \text { Area } \\
\text { Central Plateau oxidized sludge as slurry in } \\
\text { the STS cask, using a new inner container } \\
\text { known as the STSCs. } \\
\text { Interim-store the sludge as slurry in STSCs } \\
\text { in either T Plant or a new facility. }\end{array}$ & $\begin{array}{l}\text { Package the sludge as RH TRU waste } \\
\text { (using either grout or an absorbent) in a } \\
\text { new facility for subsequent shipment to } \\
\text { WIPP. }\end{array}$ \\
\hline 6 & $\begin{array}{l}\text { - } \\
\text { Petrieve sludge from K West Basin. } \\
\text { Central Plateau the un-oxidized sludge as } \\
\text { slurry in the STS cask, using a new inner } \\
\text { container known as the STSCs. } \\
\text { Interim-store un-oxidized sludge as slurry } \\
\text { in STSCs in either T Plant or a new facility. }\end{array}$ & $\begin{array}{l}\text { Oxidize the uranium metal in a new } \\
\text { facility using ambient pressure, warm- } \\
\text { water treatment. Elutriation (gravity } \\
\text { separation of lighter particles by using a } \\
\text { vertically directed liquid flow) can } \\
\text { optionally be performed on the Container } \\
\text { Sludge waste stream, prior to oxidation, } \\
\text { to separate the small fraction (less than } \\
\text { 20\%) of material containing uranium } \\
\text { metal from the larger fraction not } \\
\text { requiring oxidation. } \\
\text { Package the oxidized sludge as RH TRU } \\
\text { waste (using either grout or an absorbent) } \\
\text { in a new facility for subsequent shipment } \\
\text { to WIPP. }\end{array}$ \\
\hline 7 & $\begin{array}{l}\text { - } \\
\text { Petrieve sludge from K West Basin. } \\
\text { Central Plateau the un-oxidized sludge as } \\
\text { slurry in the STS cask, using a new inner } \\
\text { container known as the STSCs. } \\
\text { Interim-store un-oxidized sludge as slurry } \\
\text { in STSCs in either T Plant or a new facility. }\end{array}$ & $\begin{array}{l}\text { Package un-oxidized sludge as RH TRU } \\
\text { waste (using grout) in a new facility. Due } \\
\text { to the immaturity of the technology, } \\
\text { packaging of the un-oxidized sludge in an } \\
\text { absorbent and subsequent oxidization was } \\
\text { not considered. } \\
\text { Oxidize the uranium metal in a new } \\
\text { facility using heated container storage for } \\
\text { subsequent shipment to WIPP. }\end{array}$ \\
\hline
\end{tabular}


Each alternative retrieves the measured $23.5 \mathrm{~m}^{3}$ of Container Sludge and $5.4 \mathrm{~m}^{3}$ of Settler Sludge as slurry, in individual campaigns, using new underwater equipment. All alternatives load sludge slurry into STSCs, transfer STSCs to the 200 Area Central Plateau, and place the STSCs in interim storage in either T Plant or a new facility. Alternative 1 oxidizes the sludge prior to transfer to interim storage, and Alternatives 6 and 7 transfer un-oxidized sludge slurries to interim storage. There is no difference between Alternative 6 and 7 during Phase 1.

Based on preliminary review of prior safety assessments for the $\mathrm{STS}^{17}$ and sludge characterization data, two cubic meters of oxidized or unoxidized Container Sludge are assumed to be loaded into one STSC. One cubic meter of oxidized or $0.3 \mathrm{~m}^{3}$ of un-oxidized Settler Sludge is assumed to be loaded separately into a STSC. Alternative 1 requires 18 STSCs and Alternatives 6 and 7 require 30 STSCs. The loaded STSCs can be shipped in the STS cask and trailer as shown in Figures 4-2.

K East Basin North Loadout Pit sludge was previously received, handled, and stored in the process cells at T Plant. Figure 4-3 shows the actual modification performed in the T Plant cells for receipt and storage of the North Loadout Pit sludge. In order to receive this material, T Plant modifications conducted in 2002 included the following:

- Canyon cell modifications for secondary containment, leak detection and pump out capability four canyon cells (number 3L, 10L, 13L, 15L) modified to store five containers each.

- Inert gas system added for purging the STS cask with a large diameter container

- Addition of below the hook hoisting and rigging hardware to the existing T Plant canyon crane

- Established the capability for make-up water addition.

- Enhanced closed circuit television for remote monitoring and surveillance.

- Four additional cells (8R, 9L, 14R, 16R) have been cleaned out, but not modified.

- Two previously cleaned cells (numbers 8R and 9L) have been reused for equipment storage and could be emptied if additional space is required.

\footnotetext{
${ }^{17}$ SNF-10823, revision 1, 2003, Package Safety Analysis Assessment for Sludge Transportation System, Fluor Hanford
} Inc., Richland Washington 
Figure 4-2 STS Cask and Trailer

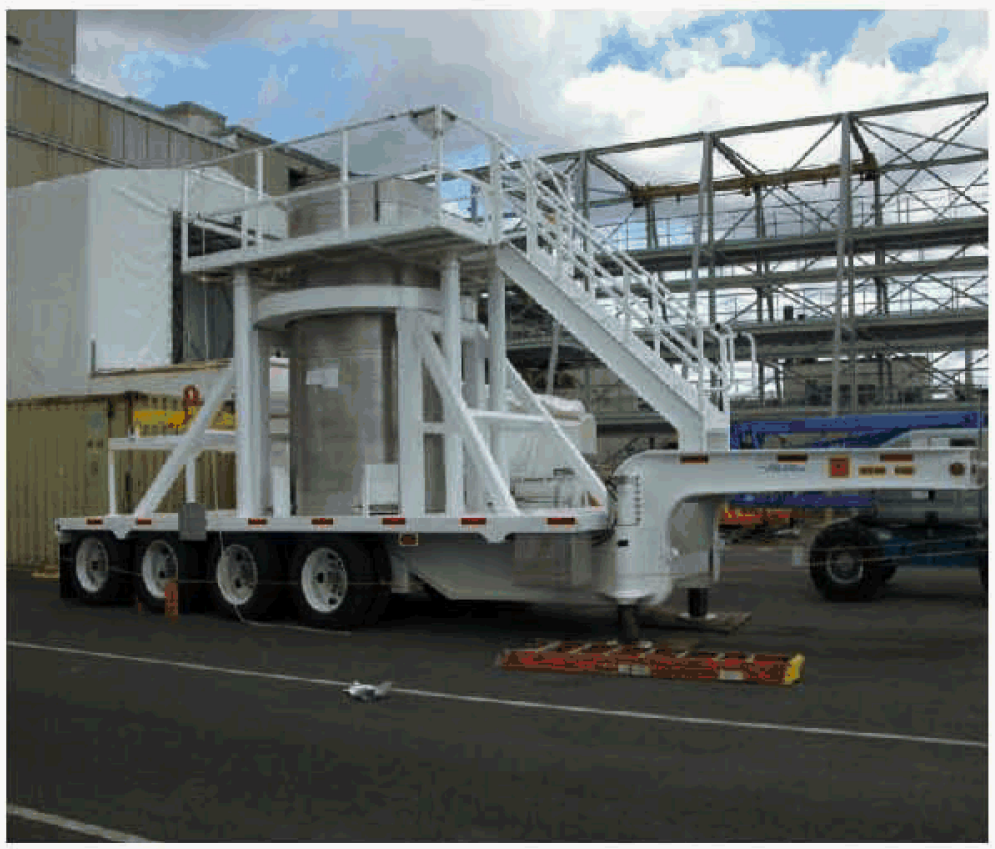

Figure 4-3 Actual Configuration of Modified Storage Cell at T Plant

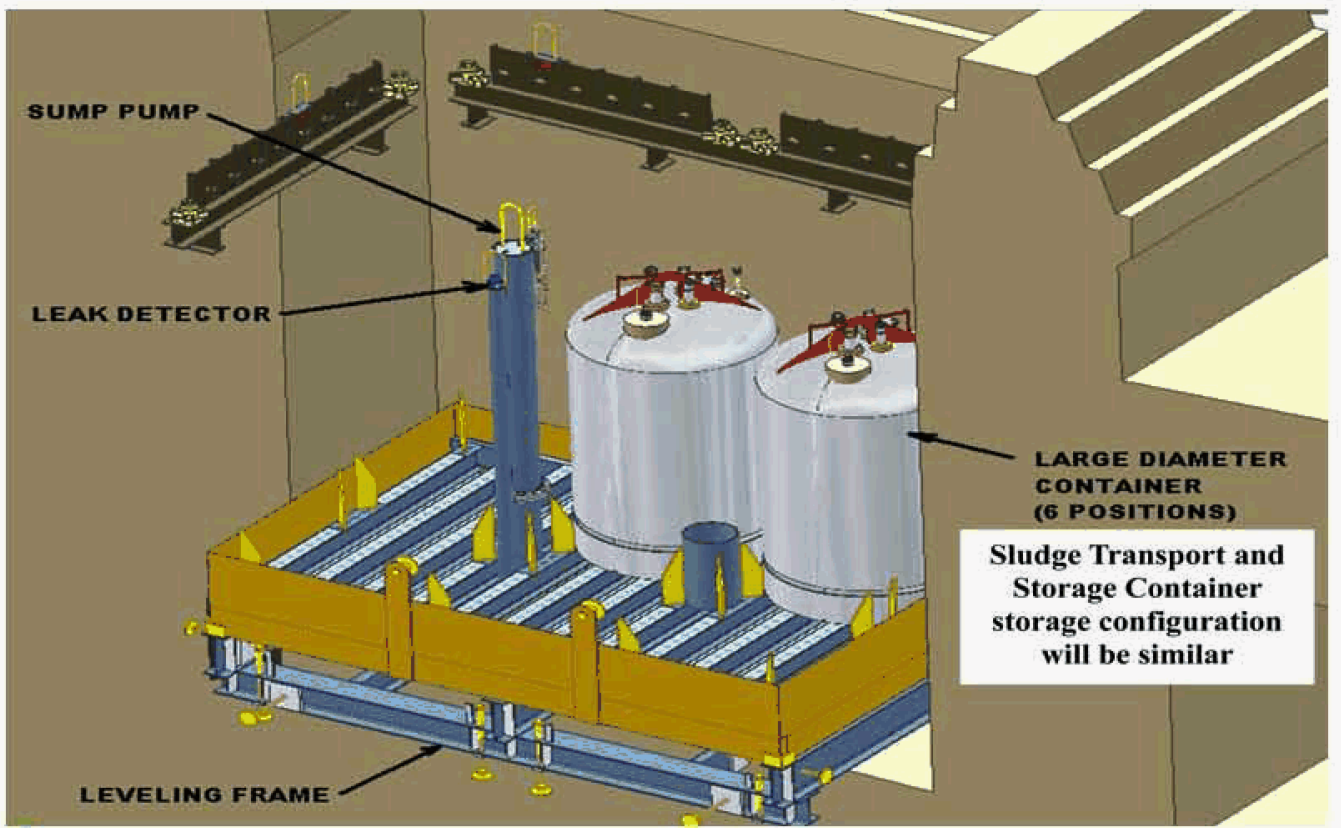

Based on preliminary estimates provided in Volume 2 , Section 7 , alternative $1 \mathrm{~T}$ requires up to four $\mathrm{T}$ Plant cells to store STSCs. Alternatives $6 \mathrm{~T}$ and $7 \mathrm{~T}$ require up to six cells to store STSCs.

Alternatives $1 \mathrm{~N}, 6 \mathrm{~N}$, and $7 \mathrm{~N}$ require comparable capabilities for STSC interim storage. In every altemative, the STSCs remain in storage until a new packaging facility is constructed in Phase 2 and readied to receive and package the sludge into approximately 3,000 Type-A 30 -gallon drums. Three drums are placed into a concrete ISC for radiological shielding and ease of future loading into RH- 
TRU 72B packages for transport to WIPP; therefore, all alternatives require approximately 1,000 ISCs.

All alternatives require new facilities to package the sludge into drums and to load the drums into RH-TRU 72B packages (three drums per canister). Approximately five years are required to package the sludge into drums (assuming one drum a shift; three shifts a day), and eight years are required to certify and ship the estimated 1,000 RH-TRU 72B packages to WIPP (assuming Hanford is allocated 50 percent of the WIPP RH-TRU waste shipping/receiving capacity during this period).

In Alternative 1 and 6, twenty percent of the slurry is separated from the retrieved Container Sludge slurry to ensure removal of the $0.5 \mathrm{~m}^{3}$ of uranium metal that requires oxidation. After oxidation, the Container Sludge is recombined. Alternative 1 is assumed to operate a new $\mathrm{K}$ West Basin underwater system to perform this separation and oxidation. Alternative 6 is assumed to incorporate the separation process, prior to oxidation, into a new packaging facility. Metal separation can reduce Container Sludge slurry oxidation time from approximately 2.5 years to 6 months. In Alternative 1 , metal separation reduces by approximately two years the time to transfer the sludge to interim storage on the 200 Area Central Plateau, when compared to oxidizing all sludge. However Alternative 1, which includes metal separation and oxidation, takes longer than Alternatives 6 and 7 to remove sludge from the River Corridor to the 200 Area Central Plateau.

In Alternatives 1 and 6, the Container Sludge slurry and all Settler Sludge slurry are oxidized, as separate batches, using one or more new vessels wherein low energy ambient pressure warm-water treatment is the oxidation method conducted to reduce the hydrogen gas generation rate from the sludge in a gradual and controlled manner. Oxidation of the uranium metal is necessary to produce a waste form suitable for transportation and disposal at WIPP. In Alternative 1 the new oxidation equipment is placed underwater in $\mathrm{K}$ West Basin. In Alternative 6 , the oxidation equipment is contained in the new packaging facility. In Alternative 7, sludge is mixed with grout and placed into 30 -gallon drums. The uranium metal in the grouted sludge is oxidized during heated storage of the drums. If a new interim sludge storage facility is utilized, it is assumed this new treatment and packaging facility will be located adjacent to it. 


\subsection{Evaluation of Alternatives using the Five Selection Criteria}

As discussed in Section 3.3, the following five selection criteria were identified in the Decision Plan for rating and ranking the three alternatives:

- Safety (Section 4.2.1)

- Regulatory/ Stakeholder Acceptance (Section 4.2.2)

- Technical Maturity (Section 4.2.3)

- Operability and Maintainability (Section 4.2.4)

- Programmatic Aspects (Section 4.2.5)

The DSB rating and ranking of the three alternatives and the "T" and "N" sub-alternatives using these five criteria is summarized in Table 4-2 and is discussed in the following sections. The information presented by the STP subject matter experts to the DSB and used by the DSB to rate and rank these alternatives is discussed in further detail in Volume 2, Sections 7 through 9.

Table 4-2. Summary of DSB Rating and Ranking of Alternatives

\begin{tabular}{|l|c|c|c|c|c|c|c|}
\hline \multicolumn{1}{|c|}{ Criteria } & $\begin{array}{c}\text { Weighting } \\
\text { Factor }\end{array}$ & $\begin{array}{c}\text { Weighted } \\
\text { Score -- 1-T }\end{array}$ & $\begin{array}{c}\text { Weighted } \\
\text { Score -- 1-N }\end{array}$ & $\begin{array}{c}\text { Weighted } \\
\text { Score -- 6-T }\end{array}$ & $\begin{array}{c}\text { Weighted } \\
\text { Score -- 6-N }\end{array}$ & $\begin{array}{c}\text { Weighted } \\
\text { Score -- 7-T }\end{array}$ & $\begin{array}{c}\text { Weighted } \\
\text { Score -- 7-N }\end{array}$ \\
\hline 1. Safety & Go/ No Go & Go & Go & Go & Go & Go & Go \\
\hline $\begin{array}{l}\text { 2. Regulatory/ Stakeholder } \\
\text { Acceptance }\end{array}$ & 25 & 75 & 75 & 100 & 50 & 75 & 25 \\
\hline 3. Technical Maturity & 20 & 60 & 60 & 60 & 60 & 20 & 20 \\
\hline $\begin{array}{l}\text { 4. Operability and } \\
\text { Maintainability }\end{array}$ & 25 & 50 & 50 & 75 & 75 & 75 & 75 \\
\hline 5. Programmatic Aspects & 30 & 90 & 60 & 120 & 60 & 120 & 60 \\
\hline \multicolumn{1}{|c|}{ Total Score } & & 275 & 245 & 355 & 245 & 290 & 180 \\
\hline
\end{tabular}




\subsubsection{Safety}

Safety input to the final three alternatives was provided following the broader input to the preliminary hazards consideration described in Section 3.2. Each of the safety disciplines (i.e., Nuclear and Process Safety, Criticality Safety, Industrial Safety and Hygiene, and Fire Protection) evaluated the three pre-conceptual design as they exist at this time. In each case, the safety disciplines used a go/no-go criterion for the alternatives, as specified in the Decision Plan. It was determined that each alternative could be configured to adequately control the respective hazards by using well established mitigation methods, and as a result, no discriminators between alternatives were identified ${ }^{18}$.

The safety analysis conducted in support of alternatives analysis is preliminary in nature, consistent with guidance provided in DOE-STD-1189-2008, as is appropriate for this stage of pre-conceptual design for the STP. As technologies are matured and the design progresses, safety will be incorporated into the design process in accordance with DOE-STD-1189-2008 and an approved safety authorization basis for the STP will be established. Appropriate levels of conservatism will be incorporated into the safety basis for the STP.

Each alternative can be configured to adequately control the respective hazards by using well-established mitigation methods, and as a result, no safety discriminators between alternatives were identified.

\subsubsection{Regulatory / Stakeholder Acceptance}

Stakeholder input has been received as public comments from past $\mathrm{K}$ Basins remedial action planning in support of the CERCLA ROD ${ }^{19}$ and ROD amendment. ${ }^{20}$ The DNFSB has also provided input in the form of DNFSB Recommendations ${ }^{21}$.

The development of regulatory documentation is achievable in all alternatives and is not a discriminator between alternatives. Since none of the alternatives treat sludge soon after removal from the Engineered Containers, and an "Explanation of Significant Differences" or an amendment to the CERCLA ROD will be needed. Development of these documents is achievable within the project schedule.

\section{The development of regulatory documentation is achievable in all alternatives and is} not a discriminator between alternatives.

\footnotetext{
${ }^{18}$ KBC-39341, revision 0, 2008, Sludge Treatment Project Pre-Conceptual Alternatives Hazards Consideration, CH2M HILL Plateau Remediation Company, Richland Washington

${ }^{19}$ EPA/ROD/R10-99/059, 1999, Record of Decision for the K Basins Interim Remedial Action, U.S. Environmental Protection Agency, Richland, Washington

${ }^{20}$ EPA, 2005, ROD Amendment for the K Basins Interim Remedial Action, U.S. Environmental Protection Agency, Richland, Washington

${ }^{21}$ Defense Nuclear Facility Safety Board Recommendations can be found at the following website http://www.dnfsb.gov/pub docs/dnfsb/rec 2007.html
} 
There is a small regulatory advantage to performing activities at a 200 Area facility that EPA considers as "on-site" (i.e., a new facility or an existing facility with no permits and no other mission) since only the administrative aspects of CERCLA and the substantive requirements of Applicable or Relevant and Appropriate Requirements need to be met. However, because only interim storage at an "off-site" facility (i.e., T Plant or a new facility) is presented in the alternatives, there is no large regulatory discriminator.

For compliance with the NEPA, DOE has the authority to integrate NEPA values into the CERCLA process for remedial actions such as this, and DOE-RL NEPA compliance officer has concurred that this is an acceptable path to satisfy the NEPA for the sludge alternatives.

Storage of sludge at T Plant (if selected) should be separate from permitted dangerous waste activities to avoid potential regulatory conflicts even though the sludge has been previously designated as a non-dangerous waste. Storage of sludge at T Plant will require a Toxic Substances Control Act (TSCA) Risk Based Disposal Approval from the EPA Region 10 coordinated through the EPA Hanford Project Lead Regulatory contact. A separate TSCA Risk-Based Disposal Approval will be required for a new interim storage facility and the new treatment facility.

There is a known chromium plume that underlies $\mathrm{K}$ Basin and has connectivity with the Columbia River, which represents a substantial environmental risk. Stakeholder values and interests are varied and, at times, competing. It is believed that the alternative that removes sludge from the $\mathrm{K}$ Basins the earliest would be considered the most favorable to advance the cleanup of Hanford's 100-K Area, which is physically constrained until sludge has been removed from the $\mathrm{K}$ West Basin. See Volume 2, Section 9 for a more detailed discussion of this subject.

\section{There is a known chromium plume that underlies $\mathrm{K}$ Basin and has connectivity with} the Columbia River, which represents a substantial environmental risk. An alternative that removes sludge from the $K$ Basins the earliest would be considered the most favorable to advance the cleanup of Hanford's 100 -K Area, which is physically constrained until sludge has been removed. 


\subsubsection{Technical Maturity}

Likely technologies to perform functions were selected based on previous studies and elimination due to perceived cost and /or complexity. These technologies are representative, but not definitive.

The DOE Environmental Management (DOE-EM) guidance on determining technology readiness ${ }^{22}$ was applied informally at the pre-conceptual STP design stage to provide a preliminary high-level assessment of technical risk associated with the three alternatives. The expectation of this high-level TRL examination was that technology maturity differences might provide discriminatory input regarding the three proposed alternatives.

Representative CTEs were identified for the three alternatives, and subject matter experts (SMEs) were assigned to prepare TRL evaluations of the critical technologies. The CTEs are described in further detail along with the TRL evaluations in Volume 2, Section 6. These evaluations were performed using the TRL questionnaires and TRL scale (see Figure 4-4) included in the DOE guidance document. These questionnaires include programmatic, technical, and manufacturing criteria. Some non-technical criteria were not considered applicable at this pre-conceptual stage. Table 4-3 identifies the CTEs and associated preliminary TRL rankings for the three alternatives.

The technical maturity information developed revealed a technology weakness unique to Alternative 7 , Phase 2 . That weakness was generally attributed to a lack of technical development completed to date for heated drum oxidation and the potential for hydrogen pressure buildup within the drum. Other CTEs (e.g. thickener and auger transport, retrieval of sludge from STSCs) were ranked low, but they are common elements of multiple alternatives and thus were not differentiators. All CTEs will require additional maturation during the project design phase.

\section{Alternatives 1 and 6 favored over Alternative 7}

- Technology weakness unique to Alternative 7 during Phase 2 due to lack of development of heated drum storage to oxidize uranium metal in grout and potential for hydrogen gas pressure buildup in drums.

- Alternatives 1 and 6 have common critical technology elements that were ranked low and require additional maturation.

\footnotetext{
${ }^{22}$ Technology Readiness Assessment (TRA)/ Technology Maturation Plan (TMP) Process Guide (March 2008), U. S. Department of Energy Office of Environmental Management
} 


\section{Figure 4-4 Technology Readiness Level Scale}

(Adopted from DOE-EM TRA/TMP Process Guide)

\begin{tabular}{lll}
$\begin{array}{l}\text { System } \\
\text { Operations }\end{array}$ & TRL 9 & $\begin{array}{l}\text { Actual equipment/process successfully operated in the operational } \\
\text { environment (Hot Operations) }\end{array}$ \\
$\begin{array}{l}\text { System } \\
\text { Commissioning }\end{array}$ & $\begin{array}{l}\text { Actual equipment/process successfully operated in a limited operational } \\
\text { environment (Hot Commissioning) }\end{array}$ \\
\hline $\begin{array}{l}\text { Technology } \\
\text { Demonstration }\end{array}$ & TRL 6 & $\begin{array}{l}\text { Actual equipment system/process system successfully operated in the } \\
\text { expected operational environment (Cold Commissioning) }\end{array}$ \\
\hline $\begin{array}{l}\text { Prototypical equipment/process system demonstrated in a relevamt } \\
\text { environmemt (Cold Engineering Scale Pilot Plant) }\end{array}$
\end{tabular}

Table 4-3. Preliminary TRL for Critical Technology Elements

\begin{tabular}{|c|c|c|c|c|c|c|}
\hline \multicolumn{2}{|r|}{ PHASE 1 CTES } & \multirow{2}{*}{\begin{tabular}{c|c}
$\begin{array}{c}\text { Function } \\
\text { (defined in Section 3.1) }\end{array}$ \\
Sludge Mobilization
\end{tabular}} & \multirow{2}{*}{$\frac{\text { TRL }}{2}$} & \multirow{2}{*}{ Alt. 1} & \multirow{2}{*}{$\frac{\text { Alt. } 6}{0}$} & \multirow{2}{*}{ Alt. 7} \\
\hline 1. & Sludge Retrieval and Transfer & & & & & \\
\hline 2. & Thickener and Auger Transport & Sludge Transfer & 2 & o & 0 & 0 \\
\hline 3. & Elutriation & Pretreatment & 2 & o & $\begin{array}{c}\circ \\
\text { Phase } 2 \\
\end{array}$ & \\
\hline 4. & $\begin{array}{l}\text { Ambient Pressure Warm Water } \\
\text { Treatment }\end{array}$ & Treatment & 3 & 0 & $\begin{array}{c}0 \\
\text { Phase } 2 \\
\end{array}$ & \\
\hline 5. & STSC Transport & Onsite Transportation & 6 & o & 0 & 0 \\
\hline 6. & STSC Loading & Sludge Transfer & 2 & 0 & 0 & 0 \\
\hline 7. & Retrieval of Sludge from STSC * & Sludge Mobilization & 2 & 0 & o & o \\
\hline 8. & $\begin{array}{l}\text { Shielded Storage (T Plant) } \\
\text { Sub-alternative "T" }\end{array}$ & Interim Storage & 6 & 0 & o & 0 \\
\hline 9. & $\begin{array}{l}\text { Shielded Storage (New Facility) } \\
\text { Sub-alternative "N" }\end{array}$ & Interim Storage & 6 & 0 & 0 & 0 \\
\hline & PHASE 2 CTEs & $\begin{array}{c}\text { Function } \\
\text { (defined in Section 3.1) }\end{array}$ & TRL & Alt. 1 & Alt. 6 & Alt. 7 \\
\hline $10 \mathrm{~A}$. & Immobilization (grout) - Oxidized & Packaging & 3 & 0 & o & \\
\hline $10 B$. & Immobilization (grout) - Unoxidized & Packaging & 3 & & & $\circ$ \\
\hline 11. & Absorbent (non-grout) - Oxidized & Packaging & 3 & o & $\circ$ & \\
\hline 12. & Heated Drum Storage (New Facility) & Treatment & 2 & & & o \\
\hline
\end{tabular}

* CTE 7 Retrieval from STSC design must be completed as part of Phase 1 - actual retrieval is part of Phase 2.

- CTE is applicable to this Alternative 


\subsubsection{Operability and Maintainability including ALARA}

Operations and maintenance of equipment within the $\mathrm{K}$ West Basin is performed remotely due to the high radiation dose rate from materials stored within the basin. Personnel are required to wear protective equipment such as a breathing respirator, anti-contamination and water barrier clothing, and safety harnesses to avoid falls. Personnel use long-reach tools and hoists to access equipment within the basin. There is limited access through grating to objects within the basin. The approximately 17 -foot water depth in the basin provides shielding to reduce the radiation exposure to personnel. The visibility within the basin water can be quickly obscured when performing operating and maintenance activities that disturb materials contained within the basin.

ALARA radiation dose estimates were prepared by $\mathrm{K}$ Basin operations personnel for each of the conceptual alternatives, as provided in Volume 2, Section 8.8. The estimated total radiation dose for operations and maintenance activities at the K West Basin was approximately the same for all three alternatives, within the accuracy of the ALARA estimate. The estimated total radiation dose for operations and maintenance activities conducted on the 200 Area Central Plateau were the same for all alternatives.

ALARA, operability, and maintainability considerations for the three alternatives favor minimizing the placement of new equipment and minimizing sludge slurry movement activities within the $\mathrm{K}$ West Basin. Alternatives $6 \mathrm{~T} / 6 \mathrm{~N}$ and $7 \mathrm{~T} / 7 \mathrm{~N}$ install less equipment and perform fewer sludge movement activities within the K West Basin than alternatives $1 \mathrm{~T} / 1 \mathrm{~N}$, since sludge oxidation (i.e., treatment) is performed in a new facility located on the 200 Area Central Plateau. All alternatives actually move the sludge as a slurry the same number of times, with some sludge slurry movement performed in the basin and other sludge slurry movement activities performed later in new facilities. For the reasons above, alternatives $6 \mathrm{~T} / 6 \mathrm{~N}$ and $7 \mathrm{~T} / 7 \mathrm{~N}$ were ranked higher for the category of operability and maintainability than Alternatives 1T/1N.

ALARA, operability, and maintainability considerations favor Alternatives 6 and 7, which minimize the placement of new equipment within the $K$ West Basin and minimize in-basin sludge slurry movement activities.

\subsubsection{PROGRAMMATIC ASPECTS}

\section{Phase 1 Schedule}

A summary of the Phase 1 schedule (removal of the sludge from the basin and interim storage) is presented in Figure 4-5. The blue portion of the bar represents the duration required for the engineering/procurement/construction portion of the activity. The green portion of the bar represents the operational duration. Since there are no differences between Alternative 6 and 7 for Phase 1 , the activity bars for Alternative $6 \mathrm{~T}$ and $7 \mathrm{~T}$ are the same. Likewise, the activity bars for Alternatives $6 \mathrm{~N}$ and $7 \mathrm{~N}$ are the same. 


\section{Figure 4-5 Phase 1 Schedule Comparison}

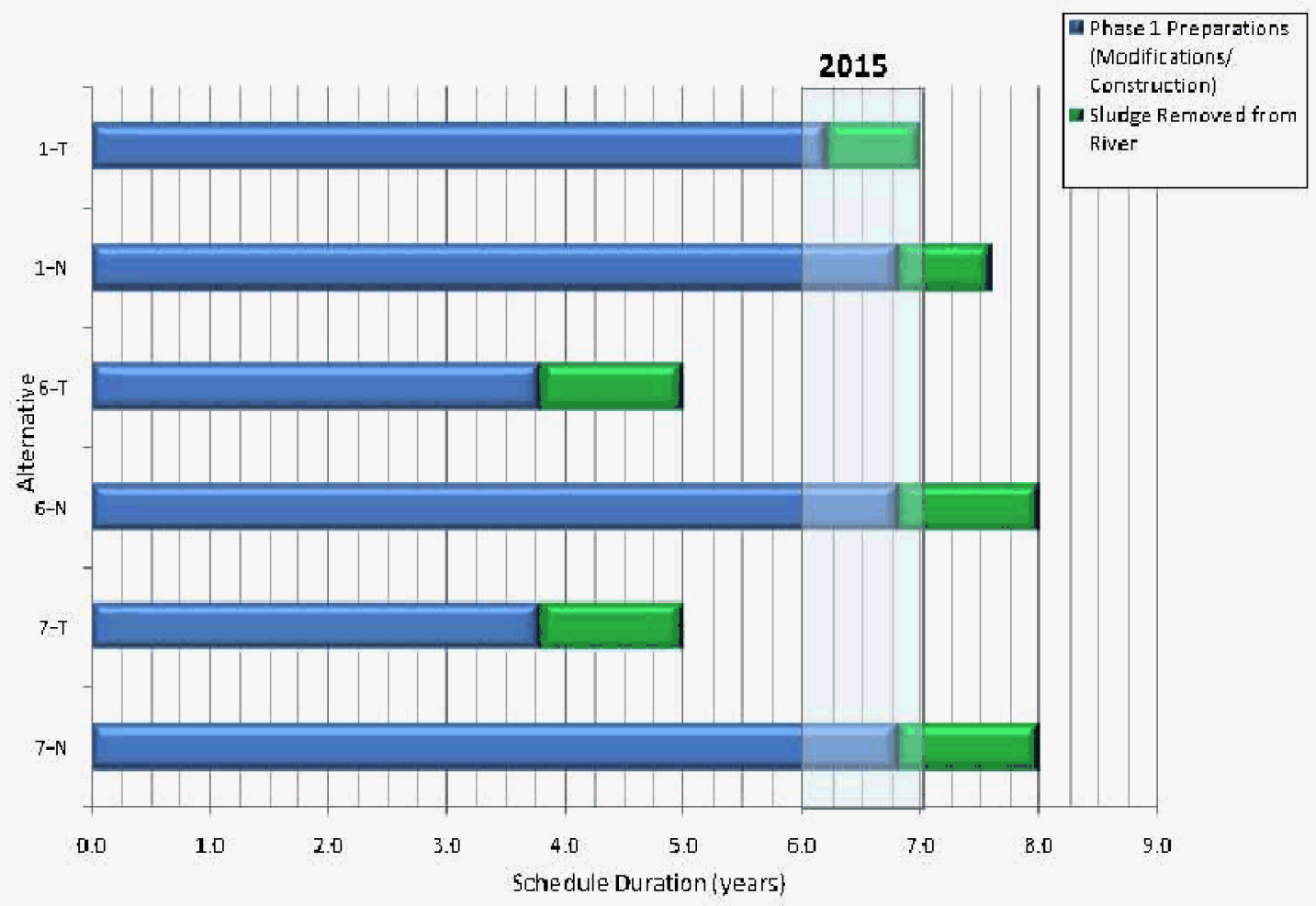

The " $N$ " altematives have a longer duration than the " $T$ " alternatives, as the critical path for the " $\mathrm{N}$ " alternatives is driven by the time to design/construct a new interim storage facility. Alternatives $1 \mathrm{~T}$ and $1 \mathrm{~N}$ include the time to design and install an oxidation system in the basin. Alternatives $6 \mathrm{~T}$ and $7 \mathrm{~T}$ have the shortest duration for Phase 1 , which is estimated to be approximately two to three years less than the other altematives.

\section{Alternatives $6 \mathrm{~T}$ and $7 \mathrm{~T}$ have the shor test duration for Phase 1 , which is estimated to be} approximately two to three years less than the other alternatives.

\section{Life-cycle Schedule}

A summary of the life-cycle (Phase 1 and Phase 2 combined) schedule is presented in Figure 4-6. In addition to the information presented for the Phase 1 schedule, the activities to design, build, and operate the packaging facility are shown, together with the durations for the ultimlate packaging and shipment to WIPP. It should be noted that this schedule was developed for comparative purposes between the altematives only and does not represent a baseline project schedule. 


\section{Figure 4-6 Life Cycle Schedule Comparison (not a baseline schedule)}

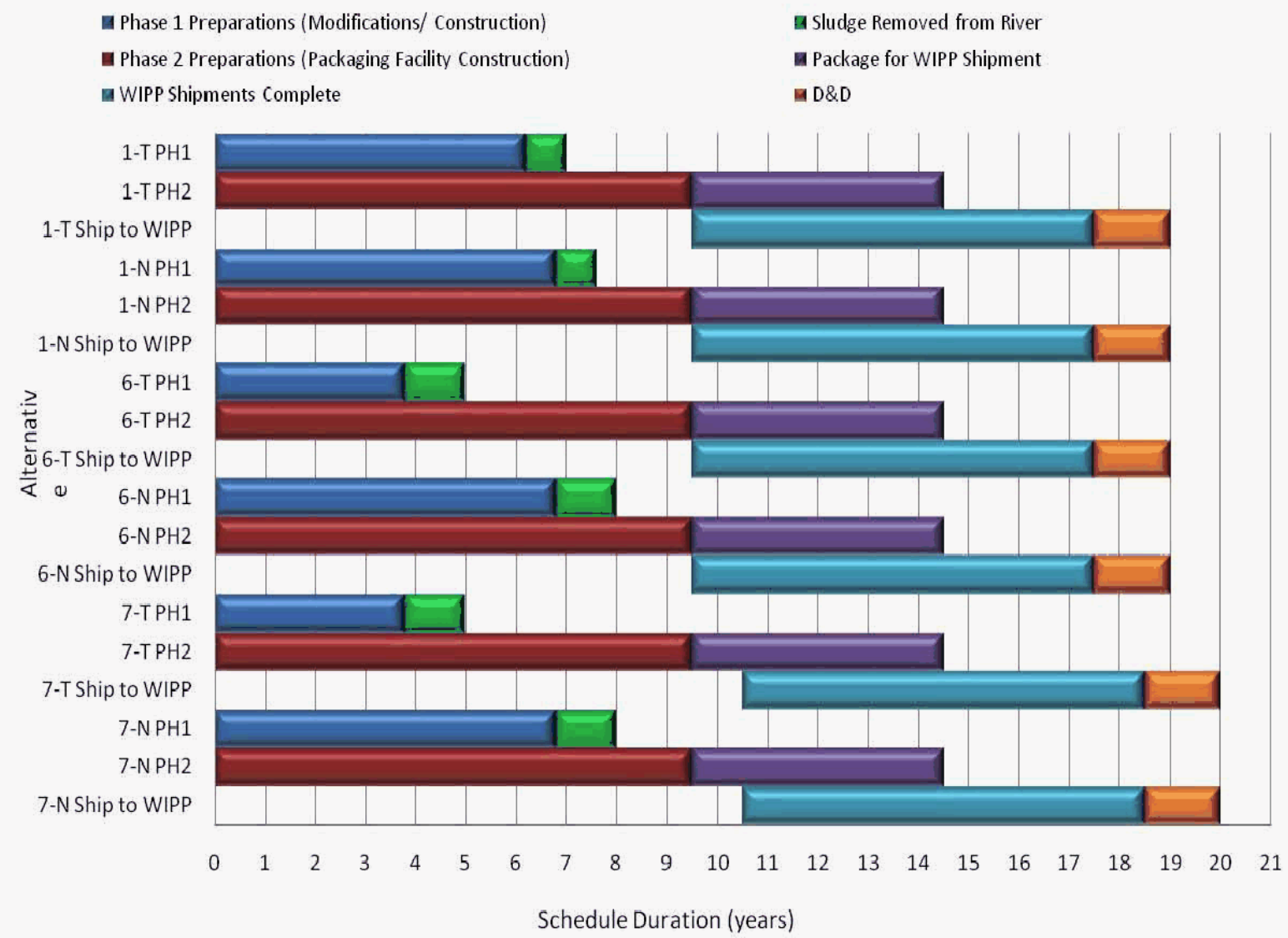

While an analysis of the Phase 1 schedule shows a clear discrimination between the alternatives, there is no such discrimination resulting from a life-cycle schedule analysis. This is because the critical path for the final disposition of the waste shipment to WIPP is driven by activities that are common to all alternatives. Each alternative will require a new facility to package the final waste form and prepare it for shipment to WIPP, and creates the same number of drums that ultimately get shipped to WIPP.

The only difference that can be seen in the life-cycle schedule analysis is the extra one year shown for Alternatives $7 \mathrm{~T}$ and $7 \mathrm{~N}$, which is due to the estimated duration for the heated drum storage for uranium metal oxidation after the sludge is grouted.

No discrimination between alternatives for life-cycle schedule, except Alternatives $7 \mathrm{~T} / 7 \mathrm{~N}$ are complete one year later due to heated drum storage to oxidize uranium metal. 


\section{Phase 1 Total Cost Estimate}

The total project cost (i.e., engineering, procurement, and construction [EPC] cost, and other project costs) and operating costs estimated ranges for Phase 1 for each alternative are shown in Figure 4-7. Costs are based on pre-conceptual estimates, and are presented in constant FY 09 dollars, escalated to the midpoint of each discrete schedule activity. Costs include contingency, which was developed through an assessment of discrete project elements. The overall contingency for each alternative is approximately $30 \%$. A $-30 \% /+50 \%$ accuracy range on EPC costs has been applied, consistent with an AACE Class 4 estimate. In the bars shown in Figure $4-7$, the green area represents $-30 \%$ range, the transition between the green and yellow area represents the mid-point, and the red area represents the $+50 \%$ range of the cost estimate. These costs have been developed for comparison purposes between alternatives only and do not reflect baseline project costs.

Figure 4-7 Phase 1 Total Cost Ranges

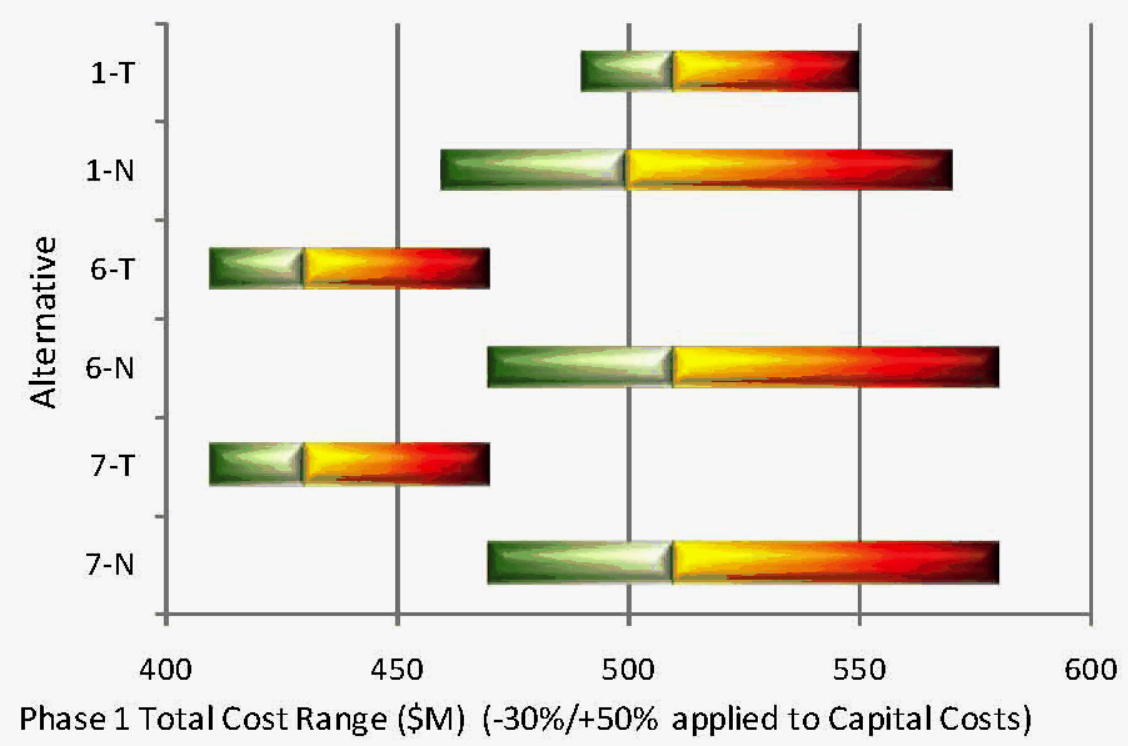

Major cost elements common to all alternatives include the sludge retrieval system, sludge transport system, container design, and procurement, slurry loadout system, and storage facility upgrades. Alternatives $1 \mathrm{~T}$ and $1 \mathrm{~N}$ also include the costs for a system to oxidize the sludge in K West Basin. Since there are no differences between Alternatives 6 and 7 for Phase 1, the bars for Alternatives $6 \mathrm{~T}$ and $7 \mathrm{~T}$ are the same. Likewise, the bars for Alternatives $6 \mathrm{~N}$ and $7 \mathrm{~N}$ are the same. 
For Phase 1, the capital costs for the " $\mathrm{T}$ " alternatives are less than the " $\mathrm{N}$ " alternatives, as the cost of a new facility is estimated to exceed the costs needed to prepare T Plant for sludge storage. Even though Alternatives $1 \mathrm{~T}$ and $1 \mathrm{~N}$ include the costs for a system to oxidize the sludge in K West Basin, the overall costs are approximately equal to those of Alternatives $6 \mathrm{~N} / 7 \mathrm{~N}$, which do not oxidize the sludge in the $\mathrm{K}$ West Basin. When the oxidation process is performed in the basin fewer STSCs are required and less work is required at the interim storage facility for Alternatives $1 \mathrm{~T} / 1 \mathrm{~N}$. The costs of this reduced scope offset the additional costs of the oxidation process for Alternatives $1 \mathrm{~T} / 1 \mathrm{~N}$.

The Phase 1 costs for Alternatives $6 \mathrm{~T}$ and $7 \mathrm{~T}$ are less than other alternatives because les work is performed at the $\mathrm{K}$ West Basin and the costs to prepare $T$ Plant are less than a new interim storage facility.

\section{Total Life-cycle Cost Estimates}

The total life-cycle costs for Phase 1 and Phase 2 for each alternative are shown in Figure 4-8. Costs are based on pre-conceptual estimates, and are presented in constant FY 09 dollars, escalated to the midpoint of each discrete schedule activity. Costs include contingency, which was developed through an assessment of discrete project elements. The overall contingency for each alternative is approximately 30\%. A $-30 \% /+50 \%$ accuracy range on EPC costs has been applied, consistent with an AACE Class 4 estimate. In the bars shown in Figure 4-8, the green area represents $-30 \%$ range, the transition between the green and yellow area represents the midpoint, and the red area represents the $+50 \%$ range of the cost estimate. These costs have been developed for comparison purposes between alternatives only and do not reflect baseline project costs. Major cost elements common to all alternatives include the new sludge packaging facility and the new ISC interim storage facility.

\section{Figure 4-8 Total Life-cycle Cost Ranges}

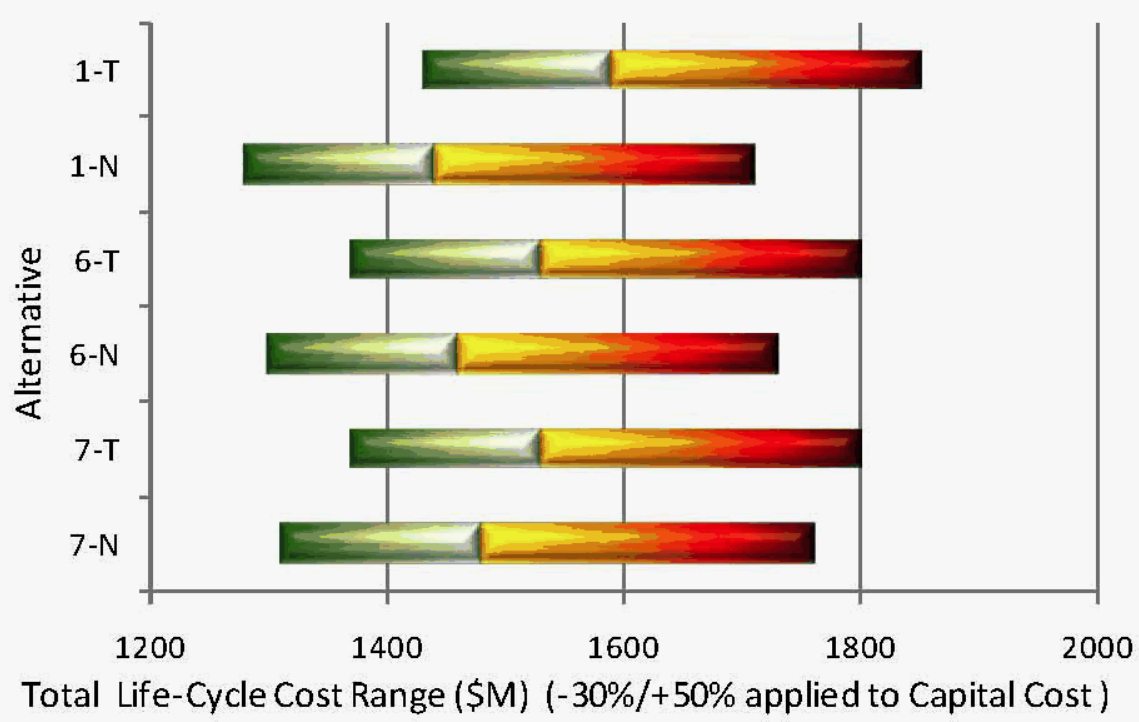


The operating costs for interim storage of sludge at T Plant were estimated to be slightly higher than those for the new interim storage facility. Therefore, alternatives that use a new facility for interim storage of sludge slurry (sub-alternatives "N") have slightly lower life-cycle costs. However, the estimated life-cycle costs for all alternatives differ by approximately $\pm 10 \%$, which is less than the $-30 \% /+50 \%$ accuracy range for the AACE Class 4 estimate. Therefore, the alternatives are not differentiated by the total life-cycle cost estimates.

Cost estimating conducted in support of alternatives analysis is preliminary and does not represent a performance baseline for the Sludge Treatment Project. The cost estimate for the selected alternative will be further refined while the technologies are matured and the design is progressed, leading to a performance baseline submittal as part of the Critical Decision-2 package.

\section{Alternatives have similar total life-cycle cost estimates.}

\section{Other Programmatic Considerations}

In addition to cost and schedule, considerations of other programmatic aspects included potential impacts to WIPP. WIPP impacts would be limited to Phase 2, since all final packaging is in that phase. Initial assessments show that waste drums of container sludge are volume limited and waste drums of settler sludge are FGE limited. Regardless of the alternative chosen, initial assessments indicate approximately 3000 waste drums will be created, which would result in about 1000 shipments to WIPP using an RH-72B shipping cask. Therefore, no differentiation can be made between the alternatives when considering impacts to WIPP.

The alternatives do not have any impacts to Yucca Mountain, Hanford Site Tank Farms, or the Waste Treatment Plant since none of the alternatives send any waste form to these locations.

Alternatives $6 \mathrm{~T}$ and $7 \mathrm{~T}$ have potential schedule interferences with KOP sludge and debris removal activities greater than the other alternatives since they remove the sludge from $\mathrm{K}$ West Basin earlier. These impacts are considered manageable through design review and schedule/operations coordination.

The "T" alternatives may impact $\mathrm{CH}$-TRU repackaging activities that are ongoing at T Plant, but are considered manageable through design review and schedule/operations coordination.

No impact to other Hanford facilities (e.g., site laboratories, canister storage building) from any of the alternatives was identified. No unique resources or limited suppliers for any of the components needed for any of the alternatives were identified. These areas were not identified as discriminators.

No differentiation can be made between the alternatives when considering impacts to WIPP or other programs. Integration with other $\mathrm{K}$ West Basin activities and $\mathrm{T}$ Plant can be managed for all alternatives. 


\subsection{DSB Recommendations}

The DSB unanimously recommended to the CHPRC that Alternative 6T should be implemented. The DSB stated the bases for preference of Alternative $6 \mathrm{~T}$ are the following:

- All alternatives can be safely implemented.

- Alternative $6 \mathrm{~T}$ was dominant for all decision criteria; sensitivity analysis did not change these results.

- Favorable risk tradeoff - the benefits of early removal of sludge from the K West Basin and River Corridor outweigh the benefit of earlier oxidation.

- Minimizes sludge handling steps in K Basin.

- Lowest Phase 1 cost / favorable sludge removal schedule compared to other alternatives.

- Use of T Plant vs. new facility - schedule outweighed uncertainty in T Plant suitability.

- No Phase 2 decisions precluded at this juncture. (This statement is true for other alternatives as well)

The DSB also identified areas of risk/ vulnerabilities with implementing Alternative 6T as listed in Table 4-4.

\begin{tabular}{|c|c|}
\hline \multicolumn{2}{|c|}{ Table 4-4. Alternative 6T Risk / Vulnerabilities } \\
\hline Risks / Vulnerabilities & DSB Comments \\
\hline Technical Maturity & $\begin{array}{l}\text { - All critical technology elements are early in the } \\
\text { maturation process and require further maturation } \\
\text { - Selected alternative needs process functions and } \\
\text { requirements development } \\
\text { - Consider parallel unit operations, alternatives } \\
\text { evaluation, value engineering, development, and } \\
\text { demonstration as part of conceptual design }\end{array}$ \\
\hline $\begin{array}{l}\text { Sludge Mobilization (Retrieval) and } \\
\text { Containment }\end{array}$ & $\begin{array}{l}\text { - Fundamental to all alternatives } \\
\text { - Need a robust design and development program } \\
\text { - Multiple pathways } \\
\text { - Include lessons learned } \\
- \text { Avoid complex mechanical devices } \\
\quad \text { underwater } \\
- \text { Consider failure modes and recovery actions }\end{array}$ \\
\hline Suitability of T Plant & $\begin{array}{l}\text { - T Plant was previously approved for K East sludge } \\
-\quad \text { Need to verify other sludge types can be } \\
\text { - } \quad \text { Quick and easy to get into } \\
\text { - Operating costs for T plant dominate Phase } 1 \text { costs } \\
\text { - If seismic and other issues preclude use of T Plant, } \\
\text { other options may be more attractive } \\
\text { - Parallel evaluation of new interim storage facility } \\
\text { until T Plant suitability is established }\end{array}$ \\
\hline
\end{tabular}




\begin{tabular}{|c|c|}
\hline \multicolumn{2}{|c|}{ Table 4-4. Alternative 6T Risk / Vulnerabilities } \\
\hline Risks / Vulnerabilities & DSB Comments \\
\hline $\begin{array}{l}\text { Adequate Simulant Development / } \\
\text { Waste Characterization }\end{array}$ & 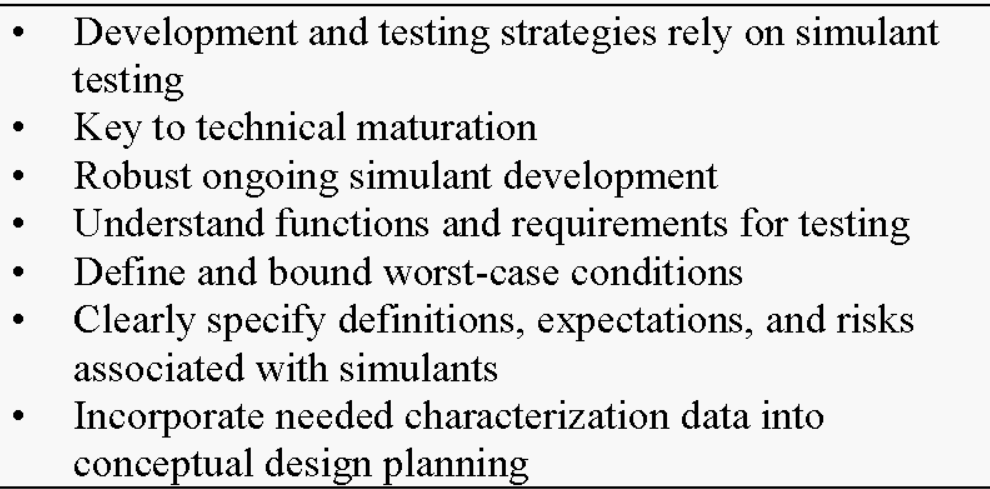 \\
\hline $\begin{array}{l}\text { Delay in Stabilizing Sludge } \\
\text { (oxidizing and immobilization) }\end{array}$ & $\begin{array}{l}\text { - Safety concerns are driven by airborne dispersibility } \\
\text { and contained chemical energy } \\
\text { - Consider oxidation during interim storage } \\
\text { - Consider "reversible" interim immobilization of } \\
\text { sludge }\end{array}$ \\
\hline $\begin{array}{l}\text { Minimize Sludge-handling } \\
\text { Evolutions }\end{array}$ & $\begin{array}{l}\text { - Include as a design objective in the functions and } \\
\text { requirements for the conceptual design } \\
-\quad \text { e.g., direct retrieval to STSCs; Loading small } \\
\text { containers in the basin }\end{array}$ \\
\hline STSC Design Considerations & $\begin{array}{l}\text { Loading/unloading, hydrogen monitoring/venting, } \\
\text { and water addition need to be considered in design } \\
\text { Make sure to include future retrieval in } \\
\text { design/demonstration process } \\
\text { - End user participation in design/ development process }\end{array}$ \\
\hline $\begin{array}{l}\text { Getting the Sludge out of the K West } \\
\text { Basin Quickly }\end{array}$ & $\begin{array}{l}\text { - Incorporate into design objectives for conceptual } \\
\text { design } \\
\text { - } \quad \text { Evaluate alternatives to accelerate sludge movement }\end{array}$ \\
\hline Equipment Maintainability & $\begin{array}{l}\text { - Evaluate failure modes / impacts and establish } \\
\text { maintenance strategy early } \\
\text { - Incorporate operations and maintenance inputs into } \\
\text { design and demonstration process } \\
\text { - Application hasn't been consistent in the past } \\
\text { in K Basin projects }\end{array}$ \\
\hline Metal Separation & $\begin{array}{l}\text { - Re-evaluate process strategy for using elutriation; } \\
\text { issues are: } \\
\quad \text { - Fine metal carryover } \\
\text { - Regulatory concerns } \\
\text { - Reactivity } \\
\text { - Process control dynamics }\end{array}$ \\
\hline Crosscutting Issues & $\begin{array}{l}\text { - ALARA Design Review } \\
\text { - Upset conditions } \\
\text { - Establish validity of key assumptions that may impact } \\
\text { schedule } \\
\quad-\text { Risk evaluation and mitigation }\end{array}$ \\
\hline
\end{tabular}




\subsection{CHPRC Recommendation}

While Section 4.3 provides the DSB recommendation to the CHPRC, this section discusses the CHPRC recommendations to DOE-RL for the STP. CHPRC recommends DOE-RL implement Alternative 6T, which retrieves and transports sludge without oxidation to $\mathrm{T}$ Plant for interim storage until a new facility is constructed on the 200 Area Central Plateau for sludge treatment and packaging. This CHPRC recommendation is consistent with the DSB recommendation discussed in Section 4.3.

Recommendation 1: Retrieve and transport sludge to $\mathrm{T}$ Plant for interim storage until a new facility located on the 200 Area Central Plateau is constructed for sludge treatment and packaging (Alternative 6T).

DOE-RL has stated that "... a key DOE objective is to remove the sludge from the $\mathrm{K}$ West Basin and River Corridor as soon as possible," 23 which will reduce risks to the environment, allow for remediation of contaminated areas underlying the basins, and support closure of the 100-KR-4 operable unit. As discussed in Section 4.1, CHPRC has identified near-term decisions (i.e., Phase 1) for accomplishing this objective and longer-term decisions (i.e., Phase 2). CHPRC recommends conducting decision making for sludge retrieval, treatment, and packaging in two Phases to enable expeditious removal of sludge from the K West Basin.

\section{Recommendation 2: Conduct decision making for sludge retrieval, treatment, and packaging in two Phases to enable expeditious removal of sludge from the K West Basin.}

\section{Recommendations}

- Retrieve and transport un-oxidized sludge to T Plant for interim storage until a new facility located on 200 Area Central Plateau is constructed for sludge treatment and packaging

- Time Phase Decisions:

- Supports expeditiously reducing environmental risks

- Supports earliest closure of $100-\mathrm{K}$ operable units

- Phase 1 (near-term) decisions for in-basin treatment and interim storage

- Phase 2 (long-term) decisions for treatment and packaging

- Continue to mature technologies for sludge loading and removal from STSCs, which is essential to timely removal of sludge from the River Corridor

- Evaluate alternatives for sludge oxidation and packaging to support Phase 2 decisions

- Complete evaluation of the suitability of T-Plant for the interim sludge storage mission, while evaluating the feasibility and cost of a simple interim storage facility

\footnotetext{
${ }^{23}$ Contract No. DE-AC06-96RL13200 - K Basin Sludge Disposition Direction, letter 08-AMCP-0151 dated March 28, 2008 from L. K. Jarnagin, Contracting Officer, U.S. Department of Energy Richland Operations Office to C. M. Murphy, President and Chief Executive Officer, Fluor Hanford Inc.
} 
In Phase 1, decisions on sludge retrieval, in-basin treatment (oxidization), and interim storage location are needed, while Phase 2 includes decisions on sludge treatment (if not conducted in Phase 1) and packaging. These decisions identified by phases are depicted in Figures 5-1 and 5-2, with further explanation below:

\section{Phase 1 Decisions:}

1. Oxidize in Basin?

Does uranium metal in the sludge need to be oxidized prior to loading the sludge into containers for interim storage?

2. Store Sludge in New Facility or T Plant?

Can T Plant be used or is a new facility required for interim storage of sludge prior to packaging for disposal?

Figure 5-1 Phase 1 Sludge Treatment and/or Storage Alternatives

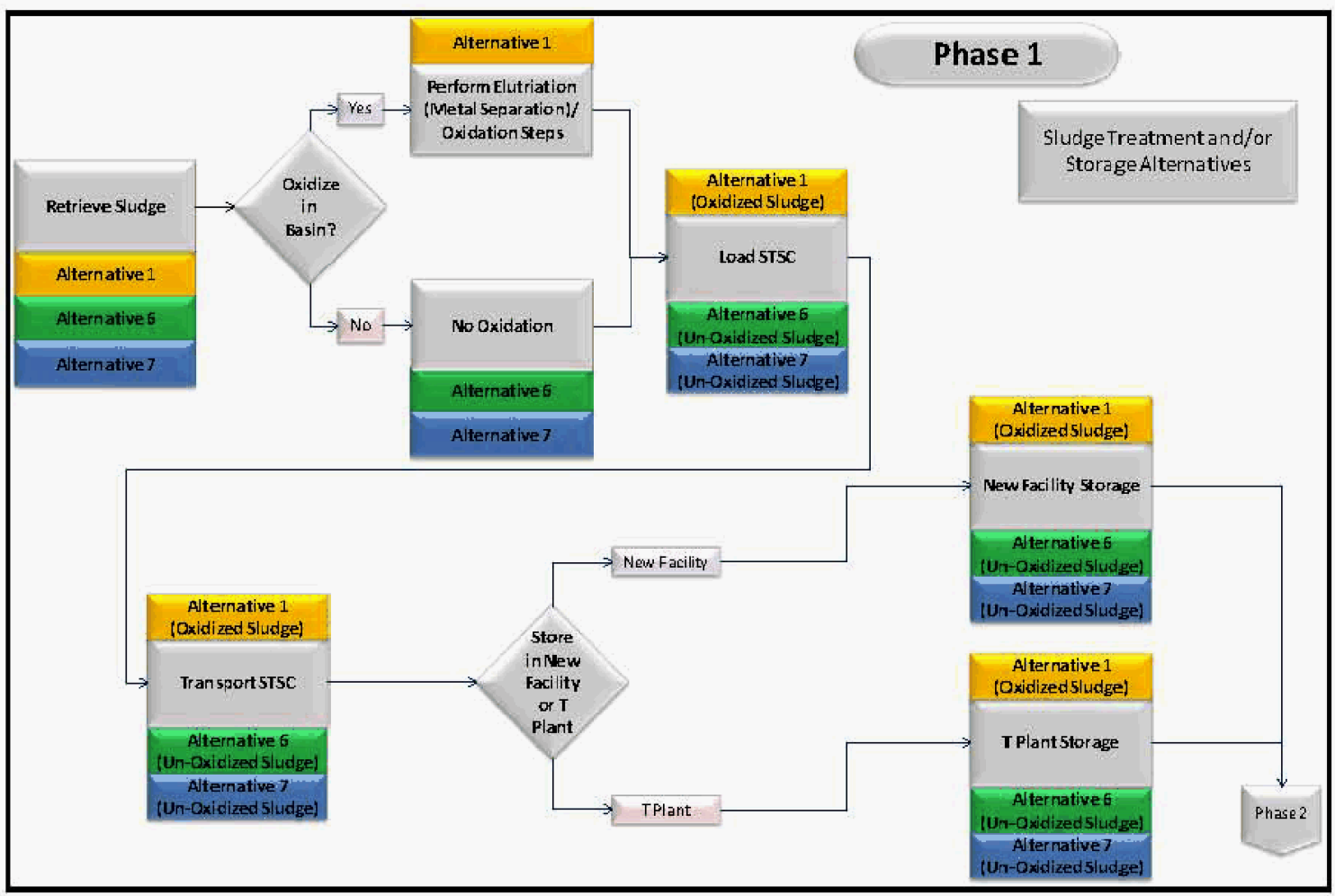


Figure 5-2 Phase 2 Sludge Treatment and/or Packaging Alternatives

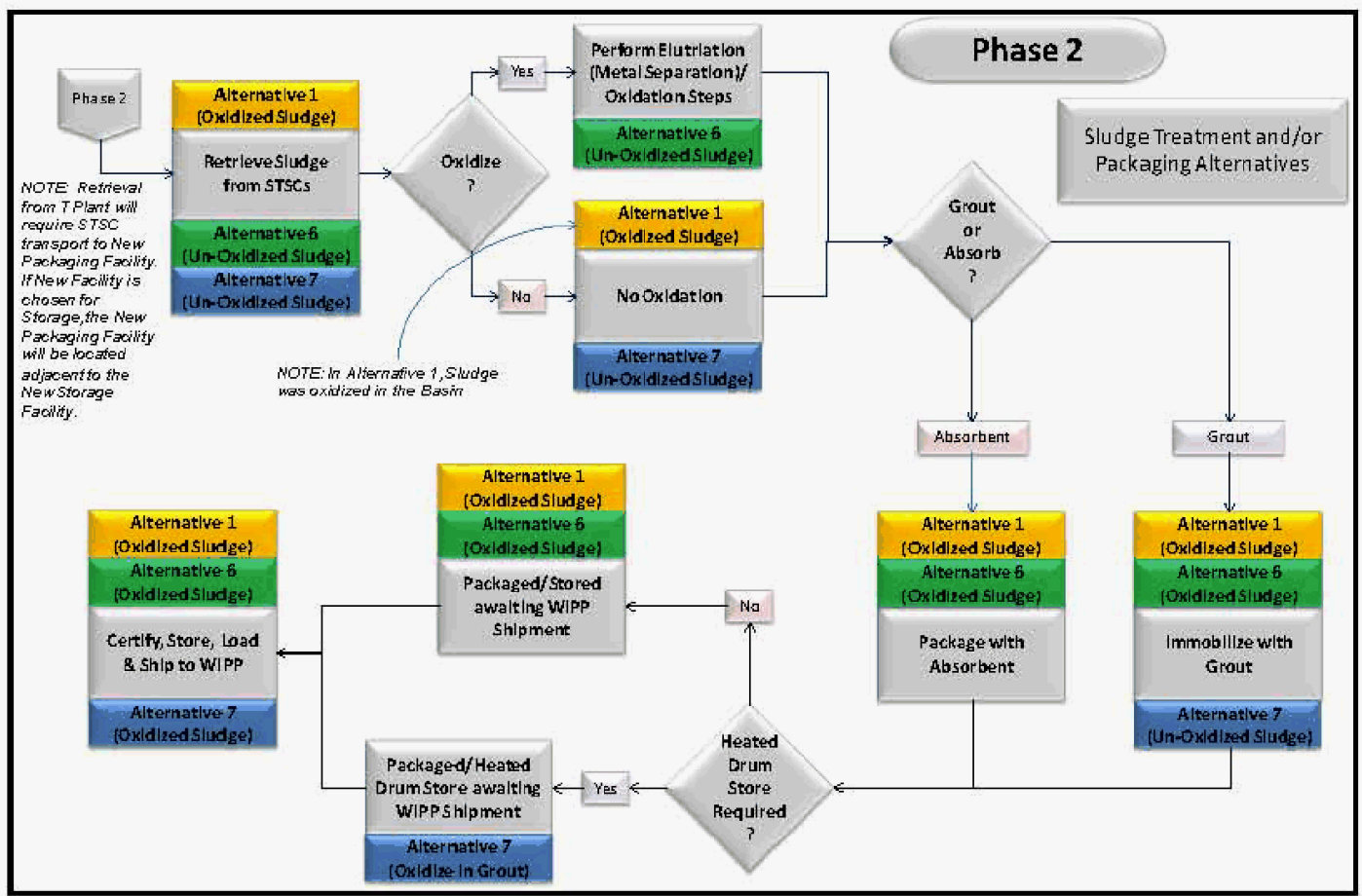

\section{Phase 2 Decisions:}

1. Oxidize?

If the sludge was not oxidized prior to removal from the $\mathrm{K}$ West Basin, does the uranium metal in the sludge need to be oxidized prior to packaging?

2. Grout or Absorb?

What is the method for packaging sludge?

3. Heated Drum Storage Required?

Does the packaged sludge require heated storage to oxidize uranium metal prior to shipment to WIPP?

The Phase 1 decisions can be made now because sludge retrieval and interim storage technologies are relatively mature, or can be matured in a timely manner, to support the project schedule. Demonstration of two sludge retrieval technologies (i.e., double diaphragm pump system and eduction system) is nearing completion. Interim storage technologies currently exist for storage of $\mathrm{K}$ East Basin sludge and can be extended to the $\mathrm{K}$ West Basin sludge. These Phase 1 decisions are independent and complimentary to the Phase 2 decisions. The Phase 1 decisions do not adversely impact the Phase 2 decisions or overall schedule and cost for the three alternatives, as shown in Section 4.2.5. 
However, fundamental to removing the sludge from the $\mathrm{K}$ West Basin is the need to transfer sludge into STSCs for interim storage on the 200 Area Central Plateau. The technology for transfer of sludge into and removal from STSCs must be determined in Phase 1. While hydraulic methods were previously used with mixed success, the STP is currently evaluating an auger system for transferring sludge into STSCs.

Recommendation 3: Technologies for the loading and removal of sludge from a STSC should be developed and demonstrated during Phase 1.

For the Phase 2 decisions, additional time is gained to complete the demonstration of sludge treatment and packaging technologies needed to mature these technologies and reduce project risks. This two-phased approach to these decisions enables sludge to be removed from the $\mathrm{K}$ West Basin while testing, design, and construction activities are completed for the sludge treatment and/or packaging system. Sections 5.1 and 5.2 provide specific recommendations for the Phase 1 decisions.

Recommendation 4: During Phase 1, continue to evaluate alternatives for sludge treatment and packaging to support Phase 2 decisions.

\subsection{Phase 1 Decision - Oxidize in Basin?}

The K West Basin sludge can be safely transported and interim stored without oxidizing prior to removal from the basin, using the existing STS safety basis ${ }^{24}$, which will need to be revised for the STSC and radiological source term if necessary. Oxidizing the $\mathrm{K}$ West Basin sludge prior to removal (Alternative 1) would substantially reduce the generation rate of hydrogen gas. Hydrogen gas generation from the sludge due to radiolysis will still occur and must be managed regardless of whether the sludge is oxidized prior to loading into STSCs. The generation of hydrogen gas from the K West Basin sludge has been extensively investigated by tests conducted with actual sludge samples and literature review of uranium metal reactions with water. ${ }^{25} \mathrm{~A}$ conservative gas generation model has been developed from this information and therefore a safety basis exists for managing hydrogen gas generation during loading, transporting, and storing sludge in large-diameter containers in the STS.

Oxidizing the $\mathrm{K}$ West Basin sludge prior to removal would also reduce the estimated number of STSCs used to store sludge from 30 containers (Alternatives 6 and 7) to 18 (Alternative 1). Oxidizing the sludge in the $\mathrm{K}$ West Basin would require sludge to remain in the basin an initial

\footnotetext{
${ }^{24}$ SNF-10823, revision 1, 2003, Package Safety Analysis Assessment for Sludge Transportation System, Fluor Hanford Inc., Richland Washington

${ }^{25}$ PNNL-17815, 2008, Uranium Metal Reaction Behavior in Water, Sludge, and Grout Matrices, C. H. Delegard and A. J. Schmidt, Pacific Northwest National Laboratory, Richland Washington
} 
estimated additional one to three years during which time interim storage facility preparation would be completed.

All three alternatives have similar estimated total life-cycle cost estimates that differ by $\pm 10 \%$. The estimated Phase 1 total costs for each alternative are dependent on whether T Plant or a new facility is used for sludge interim storage. Alternatives 6 and 7 have the same estimated Phase 1 total costs. If T Plant is used for sludge interim storage, the Phase 1 total costs are estimated to be approximately $15 \%$ less for Alternatives 6 and 7 than Alternative 1 . If a new facility is constructed for sludge interim storage, the Phase 1 total costs are approximately the same for all three alternatives.

Implementing Alternative 6 affords additional time to mature the candidate oxidization treatment technologies to support Phase 2. Alternative 7 oxidizes sludge after packaging using a heated drum storage facility. The heated drum oxidization technology requires further development and testing to mature this technology to support Phase 2 decisions.

Therefore, based on consideration of safety, ALARA, environmental risk reduction, and cost, the in-basin oxidization treatment step included in Alternative 1 does not need to be implemented in Phase 1.

Recommendation 5: Sludge should be removed from the $\mathrm{K}$ West Basin without oxidization and transferred to an interim storage facility located on the 200 Area Central Plateau.

\subsection{Phase 1 Decision - Store in New Facility or T Plant?}

As described in Section 4.2, the attributes that differentiate between the use of T Plant or a new interim storage facility for each alternative are safety (seismic), Phase 1 project cost, Phase 1 total cost, and Phase 1 schedule. All alternatives can be safely implemented and have similar life-cycle costs.

A seismic screening analysis (HNF-36856) ${ }^{26}$ of the T Plant structure was performed in 2007 as part of an evaluation of using $T$ Plant for additional solid waste management activities. This analysis used the safety system design criteria from DOE-STD-1189-DRAFT, information from a 2002 seismic evaluation for storage of K Basin sludge in T Plant (HNF-6033), ${ }^{27}$ and a larger earthquake excitation based on the 2007 WTP response spectra. This analysis was performed using a conservative equivalent static nonlinear methodology.

\footnotetext{
${ }^{26} \mathrm{HNF}-36856,2008$, T-Plant Seismic Screening Analysis for Project W-591 Solid Waste Processing Center, M-91 Solid Waste Processing Facilities Project, Fluor, Richland Washington

${ }^{27} \mathrm{HNF}-6033$, revision 1A, 2002, Seismic Evaluation of the T Plant 221-T Building for Interim Storage of K Basins Sludge, 200 West Area, Hanford Site, Fluor Hanford, Richland Washington
} 
HNF-6033 and HNF-36856 conclude the following:

1. T Plant (i.e., Building 221-T) roof will fail during an SDC-3-level seismic event and requires reinforcing. HNF-36856 (page A-4) stated "The use of high tensile strength material, such as glass or carbon fiber-reinforced polymer on the top surface of the roof is one potential strengthening measure."

2. "Building 221-T cannot meet SDC-3 Limit State D requirements."

3. "Building 221-T cannot be shown to meet SDC-3 Limit State C requirements using the conservative equivalent static nonlinear methodology. However, it is likely that the building can be shown to meet Limit State $\mathrm{C}$ requirements if a dynamic nonlinear seismic analysis is performed. (The roof would still require reinforcement.)"

4. The building meets PC-2 (or SDC-2 Limit State B) requirements.

These reports did not investigate structures other than the 221-T building (i.e. T Plant). Specifically, these seismic analyses did not investigate the HVAC system including the stack.

DOE-STD-1189-2008 (page A-2) states: "In conceptual design, if there are no bases for defining seismic-related design basis accidents, Hazard Category 2 facility structural designs must default to ANSI/ANS 2.26 SDC-3, Limit State D. If the hazards analysis conducted during subsequent stages of design shows that unmitigated consequences are less than the threshold criteria for seismic design category (SDC)-3 ... then this may be reflected in the evolving design stages." (Acronym definition added.)

The seismic design category must be reduced from SDC-3, Limit State D, if T Plant is to be used for interim storage of K Basin sludge. If the seismic design category is reduced to SDC-3, Limit State $\mathrm{C}$, then a dynamic nonlinear seismic analysis of $\mathrm{T}$ Plant needs to be performed to the requirements of DOE-STD-1189-2008 and DOE-STD-1020-2002 and the roof failure mitigated. If the seismic design category for T Plant can be reduced to SDC-2, Limit State B (formerly PC-2), then the building can be used without mitigation of the roof. For either option, the HVAC system and other critical systems must be evaluated for their ability to meet seismic requirements.

For Alternatives 6 and 7, the Phase 1 total costs are estimated to be $10 \%$ to $20 \%$ less if T Plant is used instead of a new facility for sludge interim storage. For Alternative 1, the Phase 1 project cost and total cost are estimated to be approximately the same if T Plant or a new facility is used for sludge interim storage. If T Plant is used, the $\mathrm{K}$ Basin sludge is estimated to be removed from the River Corridor one year (Alternative 1) to three years (Alternatives 6 and 7) earlier than if a new facility were constructed and operated for sludge interim storage. 
There are significant schedule and cost benefits with using $\mathrm{T}$ Plant instead of constructing and operating a new facility for interim storage of $\mathrm{K}$ Basin sludge. Using $\mathrm{T}$ Plant for sludge interim storage will expedite removal of sludge from the River Corridor and reduce the Phase 1 total costs. However, the unpredictable outcome of the seismic review for T Plant may negate these schedule and cost benefits. Therefore, it is prudent to proceed with further design activities for $\mathrm{T}$ Plant and a new interim storage facility until the seismic review is completed and the suitability of the T Plant is verified; and the feasibility and any cost or schedule advantages of a new interim storage facility are determined. Furthermore, if Phase 2 sludge treatment and packaging is delayed beyond the approximately 7 years assumed duration for T Plant interim storage operations, construction of a new interim storage facility might be more cost effective due to the higher operating costs for T Plant.

\section{Recommendation 6: Retrieve and transport sludge to T Plant for interim storage.} Complete evaluation of the suitability of $T$ Plant for the interim sludge storage mission, while evaluating the feasibility and cost of a simple interim storage facility.

\subsection{CHPRC Actions to Mitigate DSB Identified Risks}

The DSB identified risks and vulnerabilities with implementing the recommended alternative, as discussed in Section 4.3. The CHPRC has listed in Table 5-1 actions that will be implemented to mitigate the DSB identified risks and vulnerabilities. These risk mitigation actions have also been incorporated into the CHPRC Implementation Plan discussed in Section 6. 
HNF-39744, Revision 0, Volume 1

STP ALTERNATIVES ANALYSIS SUMMARY REPORT

\begin{tabular}{|c|c|c|}
\hline \multicolumn{3}{|c|}{ Table 5-1. CHPRC Actions to Mitigate DSB Identified Risks } \\
\hline $\begin{array}{c}\text { DSB Identified } \\
\text { Risks / Vulnerabilities }\end{array}$ & DSB Comments & CHPRC Risk Mitigation Actions \\
\hline Technical Maturity & $\begin{array}{l}\text { - All critical technology elements are early in the } \\
\text { maturation process and require further maturation } \\
\text { Selected alternative needs process functions and } \\
\text { requirements development } \\
\text { - Consider parallel unit operations, alternatives } \\
\text { evaluation, value engineering, development, and } \\
\text { demonstration as part of conceptual design }\end{array}$ & $\begin{array}{l}\text { - During the project Definition Phase (i.e. between CD-0 and CD- } \\
\text { 1): } \\
\text { The STP functional design criteria (FDC) document will } \\
\text { be revised to reflect the DOE approved path forward for } \\
\text { sludge treatment. The FDC document will include } \\
\text { nominal as well as bounding operating conditions. The } \\
\text { FDC document will be maintained and updated as } \\
\text { necessary throughout the project life. } \\
\text { A TMP will be prepared for the STP following the } \\
\text { guidance of the DOE Office of Environmental } \\
\text { Management's Technology Readiness Assessment (TRA) } \\
\text { / Technology Maturation Plan (TMP) Process Guide } \\
\text { (March 2008). }\end{array}$ \\
\hline $\begin{array}{l}\text { Sludge Mobilization (Retrieval) and } \\
\text { Containment }\end{array}$ & $\begin{array}{l}\text { - } \quad \text { Fundam ental to all alternatives } \\
\text { Need a robust design and development program } \\
\text { - Multiple pathways } \\
-\quad \text { Include lessons learned } \\
\text { - } \text { Avoid complex mechanical devices } \\
\quad \text { underwater } \\
\text { - Consider failure modes and recovery } \\
\quad \text { actions }\end{array}$ & $\begin{array}{l}\text { - The STP is pursuing multiple pathways for retrieving sludge } \\
\text { from engineered containers as well as from a loaded STSC. The } \\
\text { STP is conducting testing of two technologies (i.e., double } \\
\text { diaphragm pump system and eduction system) for retrieving } \\
\text { sludge from engineered containers. These technologies will also } \\
\text { be evaluated for retrieving sludge from a loaded STSC. } \\
\text { An auger system is also being tested for transferring sludge from } \\
\text { a vessel underwater in the basin into a STSC. } \\
\text { These sludge retrieval technologies were identified based on } \\
\text { lessons learned from the hydraulic transfer of sludge slurry used } \\
\text { to consolidate the K East Basin sludge into engineered containers } \\
\text { within the K West Basin. } \\
\text { Lessons learned from retrieving sludge from Settler Tanks and } \\
\text { KOPs will be incorporated into retrieving sludge from } \\
\text { engineered containers and STSCs. } \\
\text { Selection of a preferred technology for sludge retrieval and } \\
\text { containment will occur using the TRA process. } \\
\text { See also the "Minimize Sludge-handling Evolutions" risk } \\
\text { category. }\end{array}$ \\
\hline
\end{tabular}


HNF-39744, Revision 0, Volume 1

STP ALTERNATIVES ANALYSIS SUMMARY REPORT

\begin{tabular}{|c|c|c|}
\hline \multicolumn{3}{|c|}{ Table 5-1. CHPRC Actions to Mitigate DSB Identified Risks } \\
\hline $\begin{array}{c}\text { DSB Identified } \\
\text { Risks / Vulnerabilities }\end{array}$ & DSB Comments & CHPRC Risk Mitigation Actions \\
\hline Suitability of T Plant & 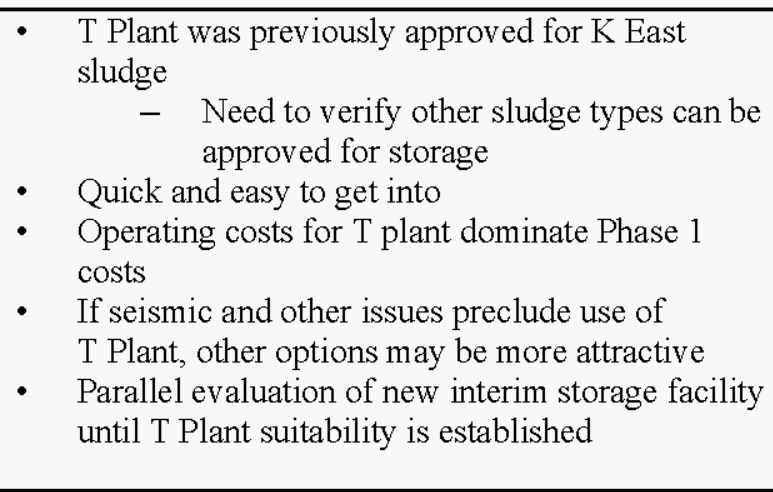 & $\begin{array}{l}\text { - The STP will evaluate in parallel the feasibility and cost of a new } \\
\text { interim storage facility while completing the evaluation of the } \\
\text { suitability of T Plant. } \\
\text { The suitability of T Plant is to be determined during the project } \\
\text { Definition Phase. } \\
\text { - A hazards analysis for storing K Basin sludge within T } \\
\text { Plant will be prepared to determine the seismic design } \\
\text { category. } \\
\text { - The existing seismic analysis for T Plant will be } \\
\text { reviewed to determine whether a new analysis is } \\
\text { required and/or whether modifications to T Plant are } \\
\text { necessary. }\end{array}$ \\
\hline $\begin{array}{l}\text { Adequate Simulant Development / } \\
\text { Waste Characterization }\end{array}$ & $\begin{array}{ll}\text { - } & \text { Development and testing strategies rely on } \\
\text { simulant testing } \\
\text { - } & \text { Key to technical maturation } \\
\text { - } & \text { Undebust ongoing simulant development } \\
\text { - } & \text { Desting } \\
\text { - } & \text { Clearly and specify definitions, expectations, and } \\
\text { - } & \text { risks associated with simulants } \\
\text { Incorporate needed characterization data into } \\
\text { conceptual design planning }\end{array}$ & $\begin{array}{l}\text { - A review of existing simulants will be conducted to determine } \\
\text { adequacy for project needs. } \\
\quad-\quad \text { Simulant limitations will be defined. } \\
-\quad \text { Expected worst-case conditions during sludge retrieval } \\
\text { from engineered containers, transfer, interim storage, } \\
\text { and retrieval from STSCs will be defined. } \\
-\quad \text { New simulant compositions will be developed as } \\
\text { necessary. } \\
\text { - As appropriate, the Data Quality Objectives process will continue } \\
\text { to be used to define sampling and analyses requirements for } \\
\text { characterization of sludge to support the conceptual design. } \\
\text { As discussed in the "Technical Maturity" risk category, the FDC } \\
\text { document will include nominal as well as bounding operating } \\
\text { conditions, which will be used during component and system } \\
\text { testing. }\end{array}$ \\
\hline $\begin{array}{l}\text { Delay in Stabilizing Sludge (oxidizing } \\
\text { and immobilization) }\end{array}$ & $\begin{array}{l}\text { - Safety concerns are driven by airborne } \\
\text { dispersibility and contained chemical energy } \\
\text { - Consider oxidation during interim storage } \\
\text { - Consider "reversible" interim immobilization of } \\
\text { sludge }\end{array}$ & $\begin{array}{l}\text { - During the project Definition Phase, the STP will evaluate } \\
\text { technologies that are capable of: (1) reducing the airborne } \\
\text { dispersibility of sludge, (2) reversible interim immobilization of } \\
\text { sludge, or (3) scavenge hydrogen / reduce uranium metal } \\
\text { corrosion } \\
\text { - If successful, these technologies could reduce } \\
\text { - consequences of potential accident conditions. } \\
\text { Selection of preferred technologies will occur using the } \\
\text { TRA process. }\end{array}$ \\
\hline
\end{tabular}

Page 54 
HNF-39744, Revision 0, Volume 1

STP ALTERNATIVES ANALYSIS SUMMARY REPORT

\begin{tabular}{|c|c|c|}
\hline \multicolumn{3}{|c|}{ Table 5-1. CHPRC Actions to Mitigate DSB Identified Risks } \\
\hline $\begin{array}{c}\text { DSB Identified } \\
\text { Risks / Vulnerabilities }\end{array}$ & DSB Comments & CHPRC Risk Mitigation Actions \\
\hline & & $\begin{array}{l}\text { Processing operations such as sludge oxidation will not be } \\
\text { conducted during interim storage of sludge in T Plant. }\end{array}$ \\
\hline Minimize Sludge-handling Evolutions & $\begin{array}{l}\text { - Include as a design objective in the functions and } \\
\text { requirem ents for the conceptual design } \\
-\quad \text { e.g., direct retrieval to STSCs; Loading } \\
\text { small containers in the basin }\end{array}$ & $\begin{array}{l}\text { - During the project Definition Phase, the STP will evaluate } \\
\text { alternatives for: (1) directly retrieving sludge from engineered } \\
\text { containers into STSCs and (2) loading containers underwater in } \\
\text { the K West Basin. } \\
\text { - These alternatives will be compared to retrieving sludge } \\
\text { from engineered containers into an intermediate vessel } \\
\text { located underwater in the K West Basin and then } \\
\text { transferring sludge from the intermediate vessel into } \\
\text { STSCs. } \\
\text { - Selection of a preferred technology for sludge retrieval } \\
\text { and containment will occur using the TRA process. }\end{array}$ \\
\hline STSC Design Considerations & $\begin{array}{l}\text { - Loading/unloading, hydrogen } \\
\text { monitoring/venting, and water addition need to } \\
\text { be considered in design } \\
\text { - Make sure to include future retrieval in } \\
\text { design/demonstration process } \\
\text { End user participation in design/ development } \\
\text { process }\end{array}$ & $\begin{array}{l}\text { - As discussed in the "Technical Maturity" risk category, the STP } \\
\text { will prepare during the project Definition Phase a FDC } \\
\text { document, which will include these functions and requirements } \\
\text { for STSC design. }\end{array}$ \\
\hline $\begin{array}{l}\text { Getting the Sludge out of the K West } \\
\text { Basin Quickly }\end{array}$ & $\begin{array}{l}\text { - Incorporate into design objectives for conceptual } \\
\text { design } \\
\text { Evaluate alternatives to accelerate sludge } \\
\text { movement }\end{array}$ & $\begin{array}{l}\text { This objective was incorporated into the evaluation of } \\
\text { alternatives and will continue to be a prime objective during } \\
\text { project Definition and Execution phases. }\end{array}$ \\
\hline Equipment Maintainability & $\begin{array}{l}\text { - Evaluate failure modes / impacts and establish } \\
\text { maintenance strategy early } \\
\text { Incorporate operations and maintenance inputs } \\
\text { into design and demonstration process } \\
\text { - Application hasn't been consistent in the } \\
\quad \text { past in K Basin projects }\end{array}$ & $\begin{array}{l}\text { - Equipment maintainability, failure modes, impacts, and recovery } \\
\text { requirements will be incorporated in the FDC document. } \\
\text { Operations and maintenance personnel will continue to be } \\
\text { involved throughout the project Definition and Execution phases. } \\
\text { Operations and maintenance personnel inputs and participation } \\
\text { will be incorporated during components and integrated system } \\
\text { testing activities. As appropriate, full-scale testing will also be } \\
\text { conducted to evaluate equipment operability and maintainability. }\end{array}$ \\
\hline Metal Separation & $\begin{array}{l}\text { - Re-evaluate process strategy for using elutriation; } \\
\text { issues are: } \\
-\quad \text { Fine metal carryover } \\
-\quad \text { Regulatory concerns } \\
- \text { Reactivity }\end{array}$ & $\begin{array}{l}\text { - Evaluation and maturation of uranium metal separation } \\
\text { technologies such as elutriation will be performed as part of } \\
\text { Phase } 2 \text { activities. } \\
\text { The recommended alternative does not include } \\
\text { separation of uranium metal from other sludge }\end{array}$ \\
\hline
\end{tabular}


HNF-39744, Revision 0, Volume 1

STP ALTERNATIVES ANALYSIS SUMMARY REPORT

\begin{tabular}{|c|c|c|}
\hline \multicolumn{3}{|c|}{ Table 5-1. CHPRC Actions to Mitigate DSB Identified Risks } \\
\hline $\begin{array}{c}\text { DSB Identified } \\
\text { Risks / Vulnerabilities }\end{array}$ & DSB Comments & CHPRC Risk Mitigation Actions \\
\hline & - $\quad$ Process control dynamics & components during Phase 1. \\
\hline Crosscutting Issues & $\begin{array}{l}\text { - } \\
\text { - } \quad \text { ULARA Dest conditions } \\
\text { - Establish validity of key assumptions that may } \\
\text { impact schedule } \\
\quad-\quad \text { Risk evaluation and mitigation }\end{array}$ & $\begin{array}{l}\text { - A preliminary ALARA review was conducted for Alternatives 1, } \\
\text { 6, and 7, as discussed in Section 4.2.4. An ALARA strategy and } \\
\text { design reviews will continue to be performed throughout the } \\
\text { project Definition and Execution phases, in accordance with } \\
\text { DOE-STD-1189-2008. } \\
\text { Upset conditions will be evaluated as part of developing the STP } \\
\text { safety basis, in accordance with DOE-STD-1189-2008. The STP } \\
\text { design will incorporate appropriate features and controls to } \\
\text { mitigate identified upset conditions. } \\
\text { Key assumptions that may impact the STP schedule and are } \\
\text { being validated during the project Definition Phase include: } \\
\text { - } \quad \text { Suitability of T Plant for interim storage of sludge } \\
\text { - Feasibility and cost of a new interim storage facility in } \\
\text { the event T Plant is not suitable } \\
\text { - Maturation of technologies for sludge retrieval, } \\
\text { containment, and transfer. } \\
\text { - STSC design, loading and sludge retrieval from loaded } \\
\text { STSC } \\
\text { The Risk Management Plan for the STP will be revised to } \\
\text { include risks identified by the DSB and the IRC. } \\
\text { Interfaces with K West Basin operations, KOP sludge } \\
\text { activities. }\end{array}$ \\
\hline
\end{tabular}




\subsection{CHPRC Implementation Plan}

The project accepts the DSB recommendation and will not perform any additional operations (e.g., oxidation) in K West Basin that are not required to transport the sludge to the 200 Area Central Plateau for interim storage. The CHPRC recommendation to transport sludge in slurry form to the 200 Area Central Plateau will achieve the DOE objective to remove the sludge from the K West Basin and River Corridor as soon as possible.

It should also be noted that this is only one aspect of the overall STP, and while it is important to set the project's strategic direction for the future, other elements of the project are equally important to be completed in the near term. Other project elements include the sampling and analysis of the Engineered Containers sludge stream, retrieval and then sampling/analysis of the settler tank sludge stream, and the feasibility evaluation of disposition of the KOP sludge stream. All work scope must be accomplished to support the DOE 2015 Vision.

Implementation of the recommendations made in Section 5 will result in significant changes to the current STP strategy, planning, and baseline. Currently CHPRC is in the midst of a contract re-baselining effort, and it will be some time before it is clear what funding is available to pace the implementation of these recommendations. In the meantime the actions recommended can be planned using the following sequencing logic categories, which are discussed in the following sections:

- Immediate actions that will be initiated as soon as DOE-RL concurs in this CHPRC recommendation. These actions help resolve significant residual risk and will provide valuable insight in the development of the STP project baseline.

- Near-term actions that should be completed prior to the initiation of conceptual design of the sludge transfer system. Establishment of a firm technical basis prior to kickoff of conceptual design with Architect-Engineering resources is one of the most important keys to success for the STP project. These include important technical maturation activities, process flowsheets and material balances, development of integrated functions and requirements, and foundational project management documentation revisions and updates.

- Mid-term actions that will need to be completed as part of the CD-1 Package that DOE must submit for approval of this Major Project activity.

\subsection{Immediate Actions}

- Revise the project strategy, mission need, and project execution plan to reflect a twophase strategy to move the engineered Container and Settler Sludge to the 200 Area Plateau for interim storage and subsequent treatment and packaging. The project execution plan will be prepared to address the 2-phase strategy and specifically address DOE Order 413.3A tailoring strategy for all WBS elements of the STP.

- A hazards analysis for storing K Basin sludge within T Plant will be prepared to determine the seismic design category and whether modifications to T Plant and support structures are necessary.

- Conduct pre-conceptual design and testing activities (if necessary) associated with: sludge retrieval, sludge transport within the Basin, and STSC loading, transportation, and 
unloading. Retrieval and loading of the STSCs are common to any future pathway to remove the sludge from the River Corridor on an expedited basis. Successful system design requires integration with the retrieval system development and testing, as well as addressing STSC loading, transport, interim storage, and future unloading functions. These activities are needed to develop information to decide which methods/technologies for the following:

- Retrieval: Evaluate double diaphragm pump system and eduction system for retrieving sludge from engineered containers. These technologies will also be evaluated for retrieving sludge from a loaded STSC. Select preferred technology for incorporation into conceptual design.

- Sludge Transport: Evaluate hydraulic slurry transfer and auger sludge transfer technologies. Select preferred technology for incorporation into conceptual design.

- STSC Loading and Unloading: Evaluate hydraulic, auger, and underwater loading and hydraulic and auger unloading technology for removing sludge from an STSC. Select preferred technologies for incorporation into conceptual design.

- Methods for reducing the airborne dispersibility of sludge, including as necessary reversible interim immobilization of sludge. If successful, these technologies could reduce consequences of potential accident conditions.

- Methods for reducing the hydrogen release from the sludge during transportation and storage

\subsection{Near Term Actions}

- Develop a design basis flowsheet for the STP phase 1 activities, identifying data gaps and assumptions which must be mitigated and captured in both the project Risk management Plan and the Technology Maturation Plan

- Revise/Update the Risk Management Plan for the STP project including risks and issues identified by the CHPRC Decision Support Board and the External Review Panel

- Develop a technology maturation plan following the guidance of the DOE Office of Environmental Management's Technology Readiness Assessment (TRA) / Technology Maturation Plan (TMP) Process Guide (March 2008).

- Identify long lead technology issues associated with Phase 2 activities that should be addressed to complete lifecycle project planning

- Update/expand the project functions and requirements to reflect the two phase strategy, and including specific technical performance requirements of the phase 1 system

- Develop Project Acquisition Plan to support both self-performed and subcontracted engineering design activities needed to implement the revised project plan 


\subsection{Mid Term Actions}

- Complete Technology Maturation activities.

- Complete conceptual design for the phase 1 activities

- Build a Project lifecycle cost and schedule that can be utilized to support baseline validation 